Board of Governors of the Federal Reserve System

International Finance Discussion Papers

Number 1011

December 2010

\title{
Fiscal Positions and Government Bond Yields in OECD Countries
}

\author{
Joseph W. Gruber \\ Steven B. Kamin
}

NOTE: International Finance Discussion Papers are preliminary materials circulated to stimulate discussion and critical comment. References to International Finance Discussion Papers (other than an acknowledgment that the writer has had access to unpublished material) should be cleared with the author or authors. Recent IFDPs are available on the Web at www.federalreserve.gov/pubs/ifdp/. This paper can be downloaded without charge from Social Science Research Network electronic library at www.ssrn.com. 


\title{
Fiscal Positions and Government Bond Yields in OECD Countries
}

\author{
Joseph W. Gruber and Steven B. Kamin*
}

\begin{abstract}
We examine the impact of fiscal positions, both the level of debt and the fiscal balance, on long-term government bond yields in the OECD. In order to control for the endogenity of fiscal positions to the business cycle we utilize forward projections of fiscal positions from the OECD's Economic Outlook. In a panel regression over the period from 1988 to 2007 , we find a robust and significant effect of fiscal performance on long-term bond yields. Our estimates imply that the marginal effect of the projected deterioration of fiscal positions associated with the recent financial crisis is to add about 60 basis points to U.S. bond yields by 2015, with effects on other G7 bond yields generally being smaller.

Keywords: Fiscal Policy, Fiscal Balances, Government Debt, Interest Rates

JEL classifications: E43, E62
\end{abstract}

* The authors are Section Chief, Trade \& Quantitative Studies, and Deputy Director of the International Finance Division, Board of Governors of the Federal Reserve System, Washington DC 20551 U.S.A. They can be reached at joseph.w.gruber@frb.gov and steven.kamin@,frb.gov. The views in this paper are solely the responsibility of the authors and should not be interpreted as reflecting the views of the Board of Governors of the Federal Reserve System or of any other person associated with the Federal Reserve System. William DeHaven and Robert Sockin provided superb research assistance. 


\section{Introduction}

As is well known, the global financial crisis has left a deep imprint on the fiscal position of the advanced economies. Figure 1 shows that fiscal deficits in the G-7 countries widened to 5 - 15 percent of GDP in 2009, and OECD forecasts have these deficits shrinking only slightly this year and next. In consequence, as shown in Figure 2, the net general government debt of these countries is projected to rise to their highest levels in many decades (with the exception of Canada). Even before the eruption of the sovereign debt crisis in Greece, policymakers and market participants had begun to focus on the potential effects of deteriorating fiscal positions on government bond yields and, by extension, private capital formation and economic growth. More recently, these concerns have become all the more acute.

There are a plethora of reasons why larger government deficits or debts might boost sovereign yields:

- Crowding out: larger deficits put greater pressure on resources, leading to a rise in the equilibrium interest rate in the economy in order to keep output from outstripping potential;

- Portfolio balance: rapid expansion of government debt may require an increase in interest rates if investors are to accept a larger share of it in their portfolios;

- Inflation expectations: fears that the central banks will monetize government debt and deficits may boost inflation expectations, thereby requiring a compensating increase in nominal interest rates; and

- Default risk: larger debts may engender fears that the government will default, also requiring a compensating increase in bond yields.

In spite of - or, perhaps, because of - the many reasons that fiscal imbalances might boost interest rates, it is difficult in practice to identify an obvious effect of the former on the latter. Figure 3 shows that, notwithstanding the trend rise in government debt/GDP ratios for most G7 countries in the past several decades, long-term government bond yields have trended down; a picture of real bond yields would show similar movements. 
Moreover, the rise in deficits and debts that has taken place most recently -- during the global financial crisis -- has not had any obvious effect on bond yields, either. Figure 4 compares the changes in expected fiscal balances for OECD countries with changes in their long-term government bond yields. The x-axis measures the change between 2007 and 2009 in the OECD's two-year-ahead projection of the fiscal balance. ${ }^{1}$ The y-axis measures the change in the long-term government bond yield between 2007 Q4 and 2009 Q4, the periods when the fiscal projections were made.

The black line indicates the expected downward sloping relationship: countries with less deterioration in fiscal balances experienced smaller increases in bond yields. However, that downward slope depends entirely on two outliers, Greece and Ireland. Absent those observations, as shown by the red dotted line, there is no relationship between the two variables. Similarly, as shown in Figure 5, the existence of a positive relationship between increases in projected government net debt ratios and increases in bond yields also depends entirely on the observations for Greece and Ireland.

Clearly, identifying a consistent effect of fiscal imbalances on bond yields requires a more complete econometric exercise that controls for a range of other influences on yields. In this paper, we build upon an extensive literature on this topic to estimate the impact of fiscal deficits and debts on long-term government bond yields for two different sets of advanced economies: the OECD economies and the G-7 countries. Following on Ardagna, Caselli, and Lane (2004), we estimate cross-country panel regressions on annual data to explain bond yields with measures of fiscal imbalances and various control variables. As in Laubach (2009), Engen and Hubbard (2005), and, in an international context, Chinn and Frankel (2005), we use forecasts of government deficit and debt variables, rather than their actual values, as explanatory variables in

\footnotetext{
${ }^{1}$ More specifically, it measures the OECD's projection of the 2011 fiscal balance that it made in 2009, minus the projection of the 2009 balance that it made in 2007.
} 
the model; this approach helps us address some of the econometric problems that make it difficult to identify an effect of fiscal performance on bond yields. We then use the estimated coefficients to gauge the likely effect of the projected future expansion of fiscal deficits and debts on bond yields around the world.

To summarize our key findings, first, we were able to estimate statistically significant effects of forecasted government deficits and debts on long-term bond yields that were remarkably robust, considering the mixed evidence uncovered by prior research. For the G-7 panel, a 1 percentage point rise in the ratio of the structural fiscal deficit to GDP boosts bond yields by 15 basis points in the long run, and a 1 percentage point rise in the net debt ratio boosts yields 2 basis points. These effects are just a little smaller than those estimated by Laubach (2009) and Engen and Hubbard (2005) for the United States alone. For the larger OECD panel, estimated fiscal effects on yields are about half those estimated for G7 countries.

Second, the expansion of fiscal deficits and debts since the onset of the financial crisis and recession should exert material effects on bond yields in the medium to long term. Based on our econometric estimates, coupled with fiscal projections published in the October 2010 IMF World Economic Outlook, we calculated the marginal effect on bond yields in the G7 countries resulting from the prospective change in fiscal positions between 2007 and 2015. By 2015, U.S. long-term sovereign yields are projected to be about 60 basis points higher than they would be if fiscal positions remain at their 2007 levels. The marginal effect of changing fiscal positions on most other G7 countries should be smaller, reflecting some combination of smaller increases in debt and greater progress in narrowing fiscal deficits in the IMF forecasts. For Japan, our estimates suggest that further fiscal deterioration will push up yields by 90 basis points, but insofar as our model does a poor job explaining Japanese yields, we put little weight on this estimate. 
The plan of this paper is as follows. Section II reviews several econometric issues that complicate the identification of the effect of fiscal performance on bond yields, and it explains how we address those issues. Section III describes our econometric methodology and reviews our core results, while Section IV reviews the results of a broad range of alternative estimations designed to assess robustness and to address specific questions about how and why fiscal performance affects bond yields. Section V describes simulations based on our core estimates that gauge the effect of the recent deterioration in fiscal performance on recent and prospective bond yields. Section VI concludes.

\section{Econometric Issues}

Other papers present reviews of the lengthy literature on the effect of fiscal performance on interest rates, so we will not repeat these summaries here. ${ }^{2}$ However, some key issues complicating the identification of fiscal effects on interest rates are worth highlighting.

To begin with, both fiscal performance and interest rates are endogenous with respect to the business cycle. A cyclical downturn in real GDP, for example, tends to lead to a reduction in the fiscal balance (widening of the deficit) as tax revenues erode and the government spends more on unemployment compensation and other income support. At the same time, interest rates decline as the monetary authorities loosen policy and the demand for money and credit declines. This introduces a spurious positive correlation between the fiscal balance and interest rates that may obscure the underlying structural negative effects discussed above.

A number of ways to control for this endogeneity have been employed by previous researchers. In their analyses of U.S. interest rates, Laubach (2009) and Engen and Hubbard (2005) abstract from current conditions by using as explanatory variables five-year-ahead projections of fiscal variables rather than their current values, and also by using as their

\footnotetext{
${ }^{2}$ See, among others, Engen and Hubbard (2005), OECD (2009), and IMF (2009).
} 
dependent variable the longer-term bond yields implied by forward markets to hold five years ahead rather than current longer-term yields. Additionally, many researchers use some measure of GDP growth or the output gap as an explanatory variable to control for business conditions, as well as a measure of short-term interest rates. Finally, taking advantage of the similarity of macroeconomic conditions within Europe, Nickel, Rother, and Rulke (2009) and Attinasi, Checherita, and Nickel (2009) focus on the impact of fiscal conditions on the spreads between yields in various European nations and those on German bonds.

In our research, we draw on a number of these approaches to control for endogeneity. We do not employ the forward interest rates utilized by Laubach (2009) and Engen and Hubbard (2004) as the dependent variable, as these are not available for a large number of countries. (We do assess their importance in an alternative specification using fewer countries.) However, as in those studies, we employ future projections of the deficits and debts, specifically two-year-ahead projections calculated by the OECD. We also, like others, use measures of short-term interest rates, inflation, and GDP growth as controls for current cyclical conditions. Moreover, to more fully abstract from current conditions and to better line up with the longer-term expectations relevant to long-term yields, we use the OECD's two-year-ahead projections for inflation and GDP growth in our equations. Finally, we use the OECD calculations of the primary and structural balance, rather than the overall balance, as measure of the fiscal balance. The primary balance excludes interest payments, thus reducing endogeneity with respect to interest rates, and the structural balance measure seeks to exclude the effects of deviations of output from potential.

A second issue that arises in estimating the effect of fiscal balances on interest rates is the relatively subtle effect they appear to exert over short time periods, as noted in the introduction. Although Laubach, Engen and Hubbard, and others have identified significant effects for the United States, results for individual foreign countries have been less consistent. Chinn and 
Frankel (2005) and Ardagna, Caselli, and Lane (2004) address this problem by pooling countries into panel data sets, thereby increasing the number of observations available to identify fiscal effects, albeit at the expense of imposing the restriction that these fiscal effects are the same across countries. In our research, we verify that time series analysis of individual countries do not yield precise estimates of the impact of fiscal variables on interest rates, and focus on panel regression estimates.

A third issue arises specifically in the context of the panel data approach. In principle, governments running larger fiscal deficits would be considered less creditworthy and thus have to pay higher interest rates. However, it is also true that if governments are considered more creditworthy for other reasons - their established record of timely repayment, the growth performance of their economy, or their political stability — they will be charged lower interest rates by the market. This, in turn, could lead them to expand their deficits as a result, leading to a negative correlation between deficits and interest rates rather than the positive correlation that would be generally assumed. Accordingly, the simultaneous correlation of both interest rates and fiscal performance with an omitted variable - underlying perceptions of creditworthinesscould bias estimates away from finding a fiscal effect on interest rates. This is apparent in Figures 6 and 7, which show no apparent relationships between the levels of fiscal balances and debts and the levels of long-term bond yields. (Recall that Figures 4 and 5 focused on changes in these variables between 2006 and 2009.) To address this problem, we use country-specific fixed effects in our model, so that estimates of fiscal effects essentially are based on the changes in fiscal variables over time rather than comparisons across country averages. ${ }^{3}$

Finally, over the last several decades, interest rates around the world have trended downward, as evidenced in Figure 3. No consensus on the explanation for this downtrend exists,

\footnotetext{
${ }^{3}$ Of course, it is possible that changes in perceived credit worthiness over time could also affect interest rates and fiscal performance, such as took place after several European countries joined the euro zone. This effect would not be captured by our fixed effects, but likely only applies to a small part of our panel dataset.
} 
but analysts point to several possible factors: declines in inflation and inflation uncertainty, the effect of the global saving glut in increasing the availability of capital, and demographic changes enhancing the demand for long-term safe assets. To control for these factors, we introduce fixed period effects into our model estimation.

\section{Basic Methodology and Results}

\section{Methodology}

Table 1 summarizes the specification of our core model. Each regression is represented by a separate column. The data are annual, and all data (including projections) are drawn from the December editions of the OECD's Economic Outlook Database. (See data appendix for details.) The dependent variable in all cases is the long-term (usually 10 year) interest rate on government bonds during the fourth quarter of the year — this timing is designed to coincide with the calculation and dissemination of the OECD's two-year projections each December. The control variables include: a short-term interest rate (usually the three-month interbank rate) averaged over the fourth quarter; the lagged dependent variable, introduced to account for persistence in the long-term yield; the two-year ahead projected rate of real GDP growth; the two-year ahead projected rate of CPI inflation; and the constant term and fixed period and country effects, not shown. This selection of control variables is broadly similar to that employed by Warnock and Warnock (2006), albeit without the data on foreign capital inflows that represent the focus of their analysis.

The OECD's two-year-ahead projections of four different measures of fiscal performance are utilized and included separately in the equations: gross government debt: net government debt, which subtracts the value of government assets; the primary balance, which excludes interest payments; and the structural balance, which excludes estimated effects on fiscal performance of deviations of GDP from its potential level. We follow the lead of most 
researchers in entering debt and deficit variables separately into the equations, as their multicollinearity reduces the precision of the estimates. However, we also estimate specifications incorporating both types of variables simultaneously (Table 11).

In all cases, the model is estimated over the period 1988 through 2007 . The starting point of the sample is dictated by data availability. The end-point was chosen to precede most of the global financial crisis, and also to allow two years of post-estimation-sample data to be used for out-of-sample evaluation. Equations 1 through 4, labeled "Full panel," were estimated using data for 19 OECD countries. ${ }^{4}$ Equations 5 through 8 used data only for the G-7 economies.

\section{Results}

By and large, the estimation results are consistent with our expectations and statistically significant. The coefficients on the lagged dependent variable are reasonably modest, in the .3 to .4 range, suggesting that other variables are explaining most of the variation in long-term interest rates. The coefficients on the short-term interest rate, inflation, and GDP growth are all positive and significant. Finally, the coefficients on the fiscal balance and debt variables are of the appropriate sign and statistically significant.

In their panel data study of OECD countries, Ardagna, Caselli, and Lane (2004) found effects of debt on interest rates only for countries with above-average levels of debt. Our finding of a straightforward linear relationship between fiscal debt and interest rates may owe to our use of projected rather than actual debt levels. We also find fiscal effects in the G-7 countries to be considerably larger than those in the OECD more generally. This could reflect that bond yields in the G-7 countries may be more market-driven than those in some of the smaller, less advanced OECD economies.

\footnotetext{
${ }^{4}$ The full sample includes Australia, Austria, Belgium, Canada, Denmark, Finland, France, Germany, Greece, Ireland, Italy, Japan, Netherlands, New Zealand, Norway, Spain, Sweden, United Kingdom, and the United States.
} 
Reassuringly, our estimates of the magnitude of fiscal effects, especially in the G-7 economies, are broadly in line with those of previous researchers. For example, Laubach (2009) and Engen and Hubbard (2004) find that a percentage point rise in the debt/GDP ratio boosts forward yields on the order of 3-4 basis points. For the G-7 countries, we find that a one percentage point rise in the net debt ratio boosts yields by 2 basis points in the long run. ${ }^{5}$ Similarly, Laubach (2009) and Engen and Hubbard (2004) find that a one percentage point rise in the ratio of the government deficit to GDP boosts yields some $19-29$ basis points, while our estimate for the G-7 countries of the long-run effect of a rise in the primary and structural balances is about 15 basis points.

The smaller fiscal effects on interest rates estimated in our panel compared with the U.S. times series regressions in Laubach (2009) and Engen and Hubbard (2004) do not seem attributable to larger effects in the United States than in other countries. We re-estimated the equations shown in Table 1, but without data for the United States, and the results were broadly similar. More likely, the difference reflects that the latter researchers use a forward yield, whereas we use a current 10-year yield. As the near-term part of the term structure of interest rates is probably less responsive to fiscal surprises than farther out on the curve, the current 10year yield does not move as much as the forward yield.

\section{Alternative Specifications and Robustness Tests}

\section{Contemporaneous Independent Variables}

In our baseline regressions most independent variables, including GDP growth, inflation, and fiscal variables, are included as two-year ahead projections under the assumption that longterm interest rates are impacted more by prospective fiscal policy and economic conditions than

\footnotetext{
${ }^{5}$ The short run effect is 1.2 basis points, but taking into account feedback effects onto the level of the lagged dependent variable, the long run effect is 2 basis points.
} 
current conditions. In order to test the importance and accuracy of this assumption, we reran our baseline regressions with current rather than projected variables.

As reported in Table 2, current GDP and inflation generally do not have a significant impact on long-term yields (particularly in the equations with debt measures), suggesting that long-term macroeconomic prospects are more important for the determination of long-term yields than current economic conditions. The coefficients on the current levels of debt (both net and gross) are for the most part not significantly different from zero. Current fiscal balance variables largely remain significant, but with slightly smaller coefficients than in the regressions in Table 1. The continued significance of the fiscal balances likely reflects the persistence of balances and the subsequent tight correlation of current and prospective balances.

\section{Five-year Five-year Forward Interest Rates}

As mentioned previously, one difference between our approach and that of Laubach (2009) is our use of the current 10-year yield as the dependent variable versus Laubach's use of five-year forward yields. By cutting off the front-end of the term structure, Laubach was attempting to look at the non-cyclical component of long-term rates. By using the current tenyear rate we have implicitly included the front-end of the term structure in our analysis.

Using a smaller sample of countries for which we have the five-year five-year forward yield (that is, the five-year yields expected to prevail five years ahead), we examine the importance of this difference in dependent variables in Table 3. For comparison, the first four columns of Table 5 repeat our baseline regressions with the smaller sample of countries but still using the 10-year yield, while the last four columns report results with the five-year five-year forward yields. We find that the estimated fiscal impact is not much different, although the coefficients are no longer significant. One thing to note is that with the forward interest rates, the short-term rate is no longer significant, as might be expected given that the near-end of the 
term structure is no longer relevant. All told, the use of forward yields does not seem essential to identify fiscal effects on bond yields, at least for this multi-country sample.

\section{Removing Inflation from the Control Variables}

As discussed earlier, one possible channel through which increased fiscal deficits and debt can impact interest rates is by increasing inflation expectations. Thus, including projected inflation as an independent variable could potentially lead us to underestimate the impact of the fiscal variables as a portion of the estimated impact of inflation on yields may in fact be attributable to fiscal policy.

However, this does not appear to be the case. As reported in Table 4, removing projected inflation from the regression generally decreases the size of the coefficients on the fiscal variables relative to our baseline regression results in Table 1. The lower estimated fiscal coefficients argue against inflation expectations being an important channel for the transmission of fiscal policy into interest rates and instead suggest that the cyclical correlation of low inflation and fiscal policy expansion has historically outweighed any effect that fiscal policy may have on inflation expectations.

The impact of fiscal policy on inflation expectations is tested directly in Table 5, which reports results from regressions with the OECD's two-year ahead projected inflation as the dependent variable. The fiscal balance variables are not significant determinants of expected inflation. Some specifications with fiscal debt positions do have significant coefficients, but with the wrong sign.

\section{Removing GDP and Short-term Interest Rates from the Control Variables}

As noted earlier, the endogeneity of fiscal positions, GDP growth, and interest rates with respect to the business cycle may give rise to a spurious positive correlation between fiscal balances and bond yields, even though, absent cyclical variations, improved fiscal positions should be associated with lower yields. Therefore, to control for cyclical effects in our baseline 
estimations (Table 1), we added short-term interest rates and projections of GDP growth as explanatory variables. However, this may have the effect of biasing downward the coefficient on fiscal positions, because it shuts down a mechanism by which fiscal expansion, for example, may affect bond yields: by providing macroeconomic stimulus that pushes up GDP growth and shortterm interest rates.

Accordingly, Table 6 examines the impact on our regression results of not including GDP growth or short-term rates as control variables. The coefficients are in general a bit smaller and less significant than those in Table 1, suggesting that the endogenity of GDP growth and shortterm rates to fiscal policy is not downwardly biasing our original estimates.

Non-linearities

Ardagna, Caselli, and Lane (2004), among others, suggest that the impact of fiscal variables on interest rates is non-linear: these variables exert little effect on yields when fiscal performance is good, but a greater effect when performance is poor and investors are more concerned about the future fiscal outlook. We test for this possibility in Table 7 by augmenting our baseline regressions with squared terms on the fiscal variables (adjusted to preserve the sign of the original non-squared variable). The signs on the squared terms generally have the wrong sign. Rather than intensifying the impact of a deficit or debt as might be expected, the squared terms generally have the opposite sign of the straight fiscal variables, implying that the impact on the interest rate becomes more muted as the level of deficits and debt increase. Accordingly, while the non-linearity hypothesis seems plausible, it receives little support from our data.

\section{Country-Specific Time Series Regressions}

Our methodology raises the question of whether the panel data regressions unduly restrict coefficients to be the same across countries, and whether it might be better to model countries separately. Tables 8 and 9 report the results of time series regressions for individual G7 countries, examining the effects of net debt and the structural balance respectively. For the time 
series regressions we include a time trend in order to capture the downward trend in interest rates over the estimation period. The results are generally weak, as coefficients often have the wrong sign or are insignificant, suggesting that cross-country variation is important for identifying the fiscal impact. Looking at the regression results, the results are strongest for Italy in terms of the impact of net debt. The coefficients on the structural balance have the correct sign, and are quite large in a number of cases; however, they are insignificant with the exception of France.

\section{The Impact of Foreign Fiscal Policy}

The advent of very large fiscal deficits globally raises the concern that bond yields in particular countries may rise not only because of the fiscal deterioration in those countries, but because of the pressure on global savings of fiscal deterioration in the rest of the world. Global capital flows make it possible that interest rates in any particular country are impacted not only by domestic fiscal policy but also by fiscal policy in other countries. The anticipated impact of foreign policy on domestic rates is contingent on the mechanism through which fiscal policy is affecting interest rates more broadly. If "crowding out" or "portfolio balance" are the operative transmission channels, then it seem likely that higher debt or deficits overseas would compete for domestic funds and drive up domestic interest rates independent of domestic fiscal policy. If instead, larger debt or deficits overseas lead to increased fears of a foreign default, i.e. higher foreign sovereign risk, it is possible that looser foreign fiscal policy could have a negative impact on domestic yields as investors seek the relative safety of domestic assets.

Table 10 examines the effect of foreign fiscal policy on domestic yields by augmenting the baseline regression with foreign fiscal variables; for each country, these are constructed as the sum of foreign (to that country) fiscal variables divided by the sum of foreign GDP. Unlike our baseline regressions, these regressions do not contain time fixed effects. As the foreign fiscal variables are similar across many of the countries in our sample, particularly for the 
smaller countries in our OECD panel, we dropped the time fixed effect to avoid problems of collinearity.

The results shown in Table 10 are mixed. The level of foreign debt does not appear to be important for the determination of domestic yields. The coefficients on foreign balances are significant but vary in sign across the primary balance and structural balance, with the foreign primary balance actually driving up domestic yields and the structural balance having a larger negative impact on domestic yields than the domestic structural balance. All told, the evidence does not provide strong support for the role of global fiscal measures in affecting bond yields.

\section{Model Simulations}

\section{Ex-post historical simulations}

How well does the baseline model explain the actual evolution of interest rates? Using the coefficients from the basic panel regression with the G-7 sample estimated through 2000, we construct dynamic simulations of G7 interest rates going forward. Figure 8 shows the simulations using the model with net debt while Figure 9 uses the model with the structural deficit. In constructing the simulations we held our estimates of period and country fixed effects constant at their 2000 levels.

By and large, both of these models do a reasonable job of tracking actual movements in bond yields, particularly given that the figures display fully dynamic simulations implemented over lengthy time periods. ${ }^{6}$ To be sure, there are some sizeable errors by the end of the simulation period in a number of countries - Canada for the model using net debt, Italy for the model using the structural fiscal balances_-but even in these cases, the models capture the broad contours of the interest rate paths. The key exception is the failure of the model with net debt to explain Japanese bond yields - it predicts substantial increases in these yields as net debt

\footnotetext{
${ }^{6}$ In a fully dynamic simulation, the predicted value of the bond yield for one period is used for the value of the lagged dependent variable in the subsequent period.
} 
accumulated, whereas actual yields declined further. Consistent with many commentaries on this subject, it is clear that issuance of Japanese government debt does not boost required yields to anywhere near the same extent as in other countries. This may be due to the home bias of Japanese investors, the entrenched nature of deflation, or some other factor not captured by our model.

\section{Projected impact of fiscal deterioration}

Table 12 uses our econometric estimates to assess the marginal impact on G7 bond yields of the projected deterioration in the fiscal position between 2007 and 2015 . The projections are derived from the October 2010 IMF World Economic Outlook (WEO). They show increases in the net debt of the G7 countries ranging from only 9 percent of GDP for Canada to 72 percent for Japan. Changes in structural balances are more mixed, in the sense that relative to 2007, by 2015 they are projected to be somewhat higher (lower deficits) in the United Kingdom, a bit lower in Canada, Germany, and Italy, and considerably lower in Japan and the United States.

In assessing the effect of these projected changes in bond yields, we faced the challenge of reconciling our estimates for the effect of debt ratios on yields with our estimates for the effect of fiscal balances. In principle, changes in fiscal balances have implications for debt ratios, and vice-versa. Therefore, their movements are not independent, and one cannot simply add the estimated effect of changes in net debt to the estimated effect of changes in fiscal balances. Instead, and at the cost of some multicollinearity, we chose to estimate a set of equations that include both debt and balance measures as explanatory variables.

As shown in Table 11, the resultant coefficient estimates are generally smaller and often less statistically significant, as we would expect. Even so, the estimates are in the same ballpark as those shown in Table 1. Accordingly, to calculate the marginal effect on G7 bond yields of projected fiscal movements, we used the estimates shown in column 8, which are based on the net debt and structural balance measures. These calculations take into account not only the 
coefficients on those two variables, but also that on the lagged dependent variable, which captures the persistence of bond yields over time and their dynamic response to shocks.

Turning to the results shown in Table 12, for the United States, the rise in net debt and deterioration of the structural fiscal balance lead to a marginal effect on bond yields of 62 basis points, holding all else equal. This is not an alarmingly large effect, but at the same time, held over many years, it may be sufficient to reduce the pace of capital formation and thus economic growth by a material extent. The estimated effects on the bond yields of most other G7 countries are considerably smaller, as more progress in fiscal consolidation leads to smaller increases in debt.

Japan is the one exception, with the structural balance projected to deteriorate even more than in the United States, and the net debt projected to rise much more rapidly. As a result, fiscal deterioration pushes Japanese bond yields up 90 basis points. However, based on the failure of the model to track historical Japanese yields, as discussed above, we are inclined not to put much weight on these results.

The estimates for Japan offer a cautionary reminder about the limitations of this type of analysis. The regression allows county-specific differences in the level of interest rates, due to the inclusion of fixed country effects, but sets the marginal impact equal across countries. It is possible that idiosyncratic aspects of the Japanese situation, including country-specific institutional arrangements might impact the marginal impact of fiscal variables. Certainly up to this point, Japan has been able to finance its large debt at low interests, a feature captured in the model by the country fixed effect, and it is possible that the institutional arrangements that have kept Japanese interest rates low in the past will continue to operate, a possibility ignored by the model forecast. 


\section{Conclusion}

Using a large panel dataset of OECD countries, we have identified a robust and significant impact of fiscal performance on long-term bond yields. Based on our estimates, by 2015, yields could be 60 basis points higher in the United States than would have been the case in the absence of the projected increases in debts and deficits since the advent of the financial crisis. Excluding Japan, whose bond yields are not well-explained by our model, bond yields in other G7 countries would be up by lesser amounts. All told, these estimates point to a material, but not overwhelmingly large, impact of the global fiscal deterioration on bond yields.

In addition to assessing the magnitude of the effect of fiscal performance on bond yields, we also explored the various channels through which that effect might have occurred. We are inclined to discount the possibility that changes in fiscal performance affected yields through their effect on perceived default risk, as the G7 governments in our sample were considered highly creditworthy. ${ }^{7}$ Our econometric results provide no evidence for the view that concerns about inflationary effects underlie the linkage between fiscal deficits and bond yields: we identify such a linkage even controlling for projected inflation; removing projected inflation as an explanatory variable does not affect our estimation results; and there is little evidence of a direct effect of fiscal performance on inflation expectations in our sample. Finally, we found no support for the concern that bond yields might experience an especially large increase because fiscal deficits around the world had all widened simultaneously_once a country's own fiscal performance is taken into account, the fiscal performance of the remaining countries in the sample had no robust, significant effect on that country's bond yields.

\footnotetext{
${ }^{7}$ It is also worth noting that estimates from other studies examining the effect of fiscal conditions on bond yields in the United States are poor empirical estimates of the likely impact of sovereign risk, as fears of sovereign default in the United States were essentially non-existent over his sample period.
} 


\section{Bibliography}

Ardagna S., F. Caselli, and T. Lane (2004) "Fiscal Discipline and the Cost of Public Debt Service: Some Estimates for OECD Countries” CEPR Discussion Paper \#4661

Aisen A. and D. Hauner (2008) "Budget Deficits and Interest Rates: A Fresh Perspective" IMF Working Paper WP/08/42.

Attinasi M, C. Checherita, and C. Nickel (2009) "What Explains the Surge in Euro Area Sovereign Spreads During the Financial Crisis of 2007 - 2009" ECB Working Paper \#1131.

Chinn, M. and J. Frankel (2005) “The Euro Area and World Interest Rates" unpublished working paper.

Engen, E. and R. G. Hubbard (2005) "Government Debt and Interest Rates” in M. Gertler and K. Rogoff, NBER Macroeconomics Annual 2004, Cambridge: MIT Press 2005

International Monetary Fund (2009), "Companion Paper-The State of Public Finances: Outlook and Medium-Term Policies after the 2008 Crisis," Washington, DC, March 6.

Laubach T. (2009) "New Evidence on the Interest Rate Effects of Budget Deficits and Debt", Journal of the European Economic Association 7 p 858-885.

Nickel C., P. Rother, and J. Rulke (2009) "Fiscal Variables and Bond Spreads: Evidence from Eastern European Countries and Turkey” ECB Working Paper \#1101.

OECD (2009), "Chapter 3: The Effectiveness and Scope of Fiscal Stimulus" in OECD Economic Outlook Interim Report, March.

Warnock, F.E. and V. C. Warnock (2006), "International Capital Flows and U.S. Interest Rates," NBER Working Paper 12560, October.

\section{Data Appendix}

All data, with the exception of forward interest rates, were taken from the OECD's December Economic Outlook starting with the 1988 edition.

Long-Term Interest Rates: For most countries the long-term rate was the 10 -year government bond yield. The rates were daily averages, with the exception of Canada (average of last Wednesday of each month), Japan, Australia, Denmark (end of month rates), France, and Ireland (last Friday of each month).

Short-Term Interest Rates: For most countries the short-term rate recorded in the Economic Outlook is the 3-month interbank interest rate. For Greece, prior to 2001 the 12-month Treasury rate was used. The rates are daily averages, with the exception of Denmark and Ireland, which are the average of the end-of-month rate, and Canada, which is the average of Wednesday rates.

Five-Year Five-Year Forward Interest Rates: Kindly provided by Clara Vega.

GDP: Real GDP.

Inflation: As measured by the deflator for private consumption.

Gross Debt: General government gross financial liabilities.

Net Debt: General government net financial liabilities. 
Primary Balance: General government primary balances through 2007. Sum of general government financial balances and general government net debt interest payments for 2008 and 2009 .

Structural Balance: General government structural balance through 2001. Cyclically-adjusted general government primary balance from 2002 to 2008. General government underlying primary balance in 2009 . 
Figure 1: Fiscal Balances for G-7 Countries

United States

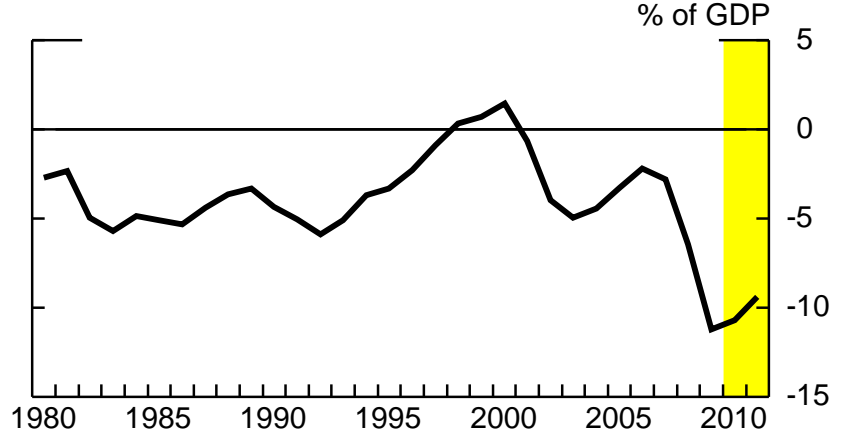

United Kingdom

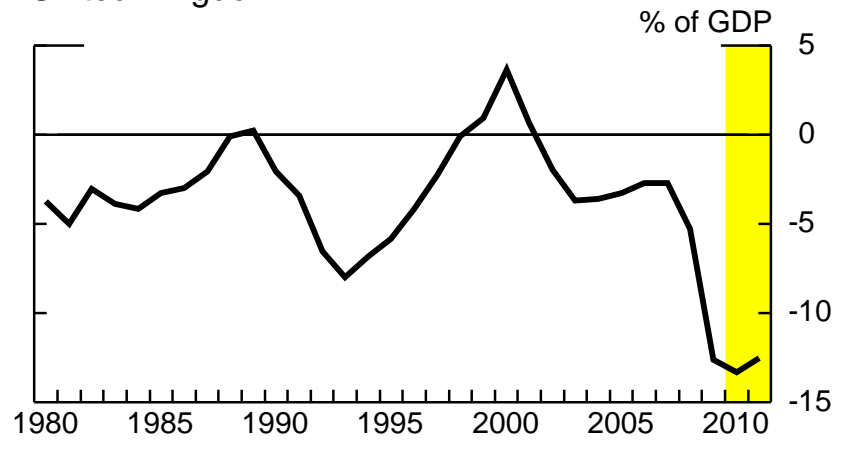

Italy

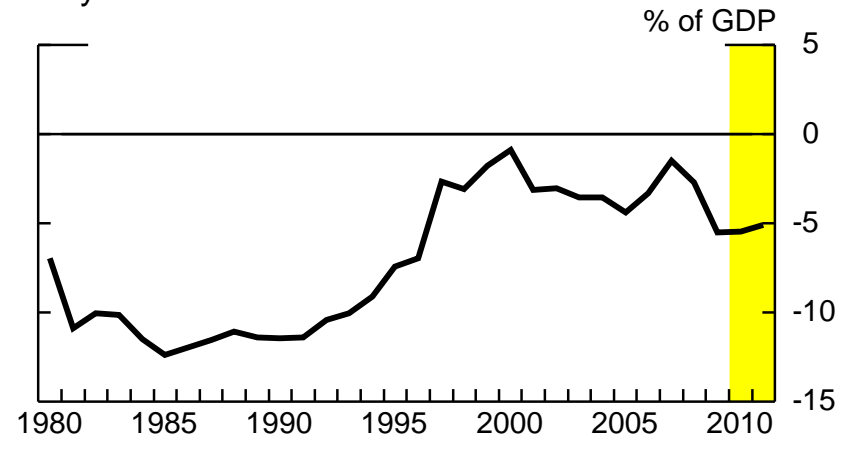

France

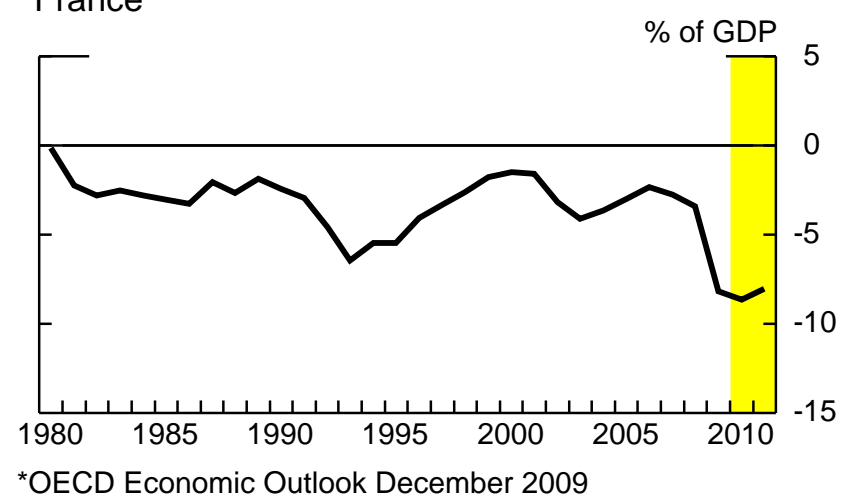

Germany

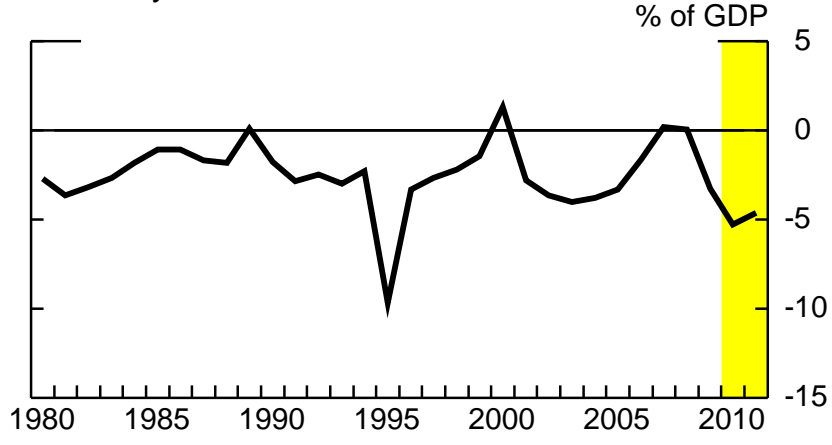

Japan

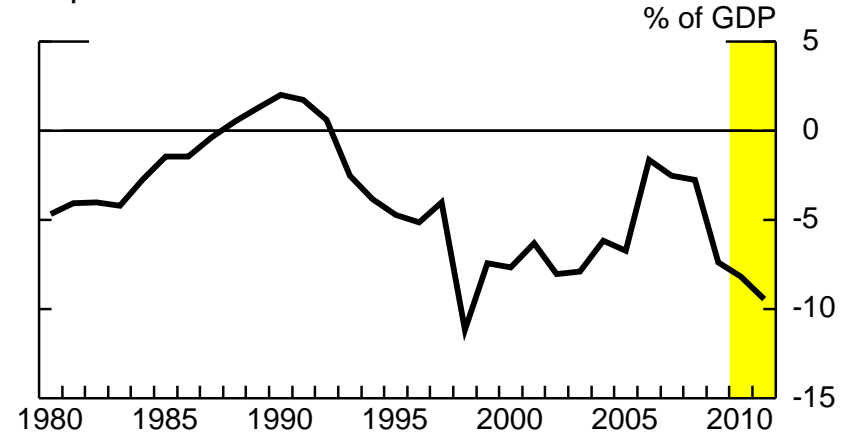

Canada

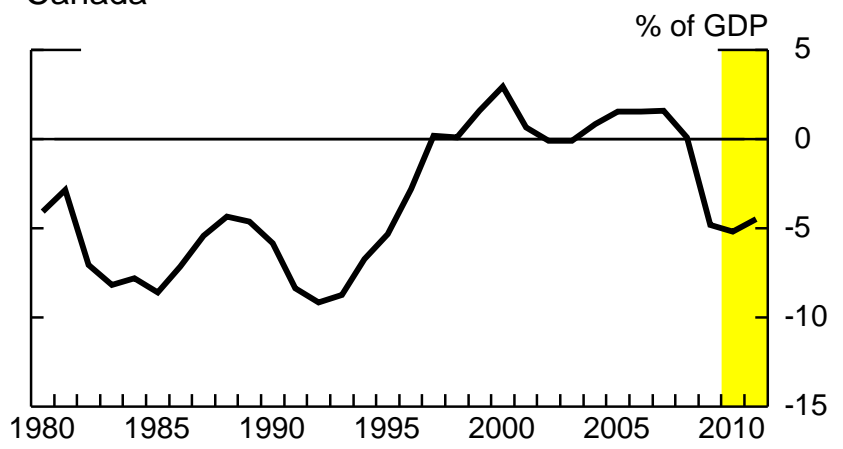


Figure 2: Government Net Debt for G-7 Countries

United States

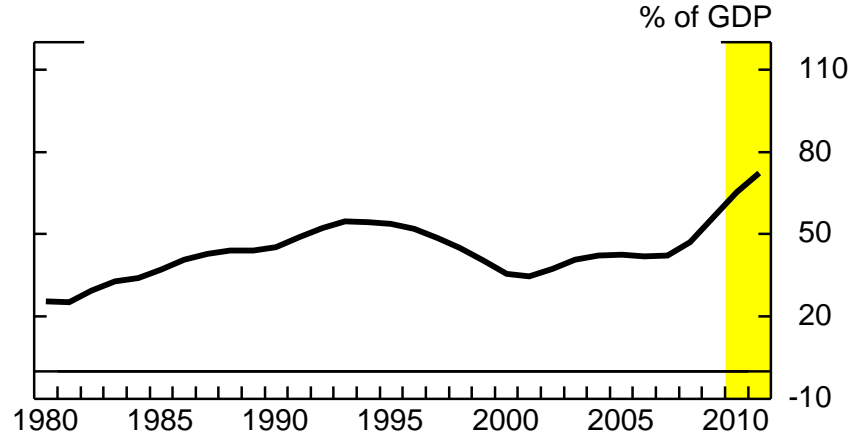

United Kingdom

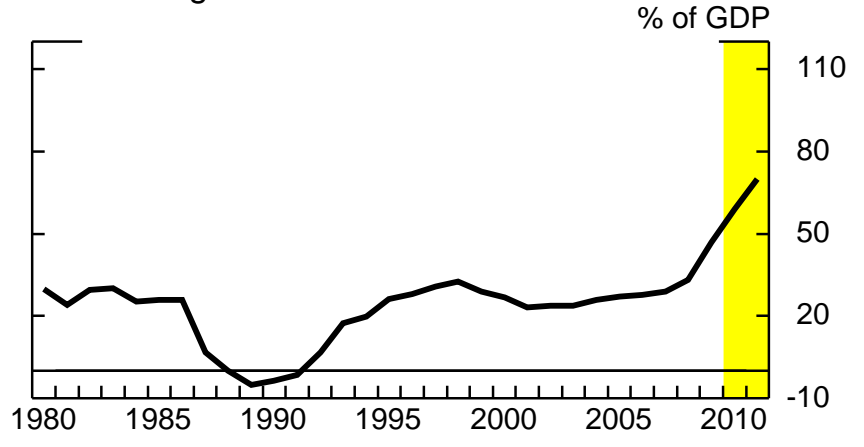

Italy

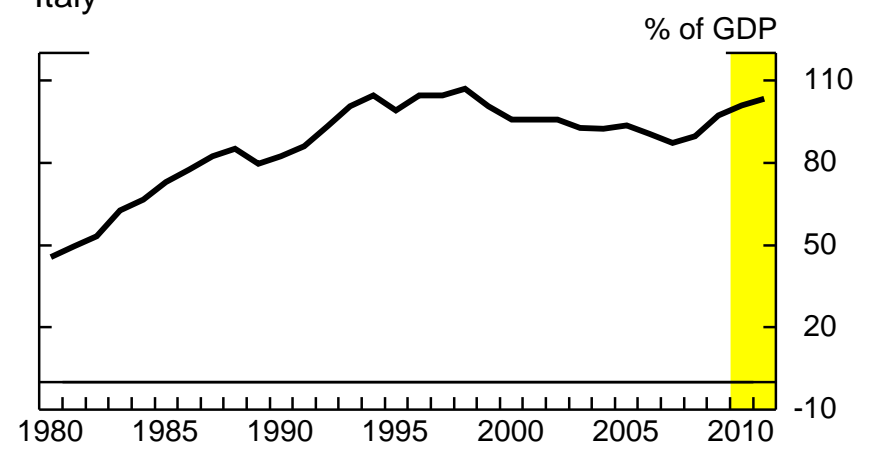

France

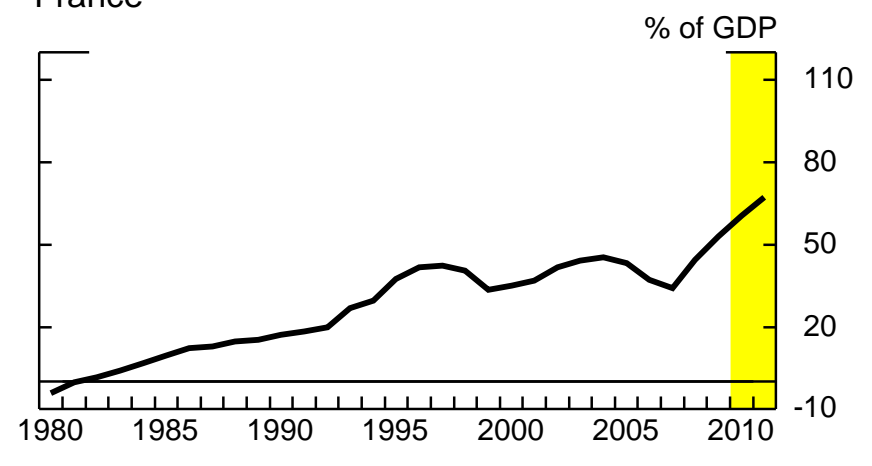

Germany

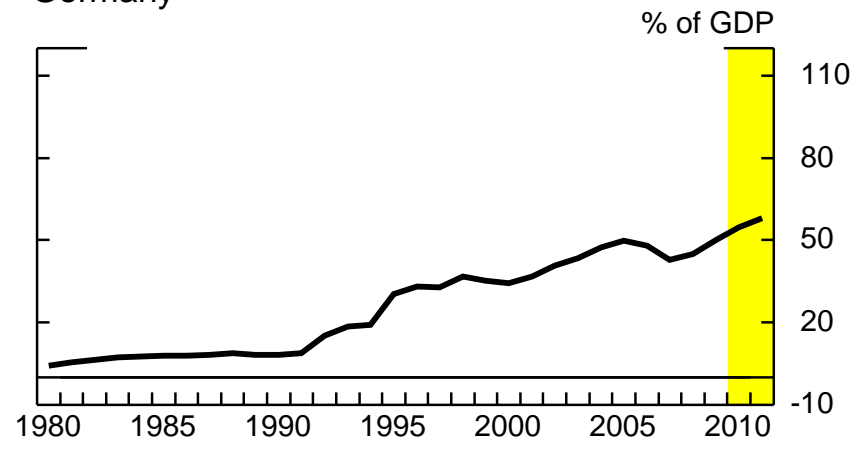

Japan

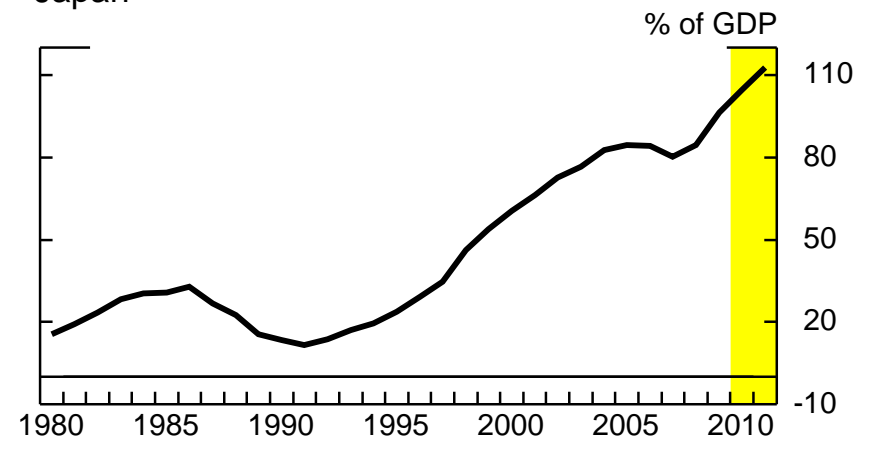

Canada

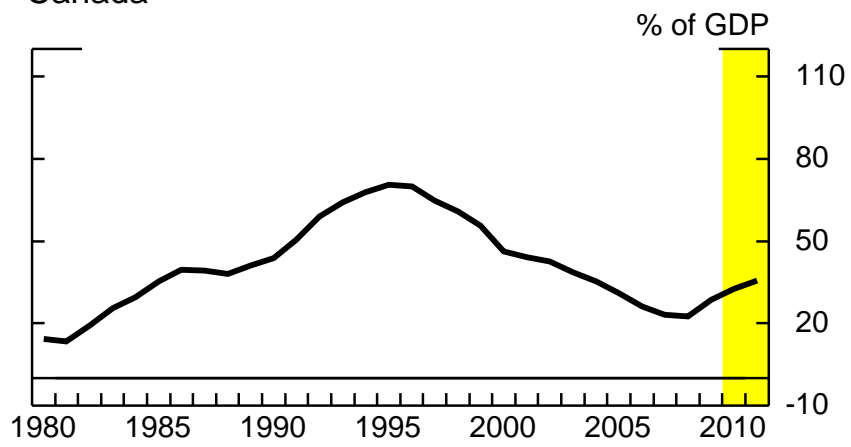

*OECD Economic Outlook December 2009 
Figure 3: Long-term Interest Rates for G-7 Countries

United States

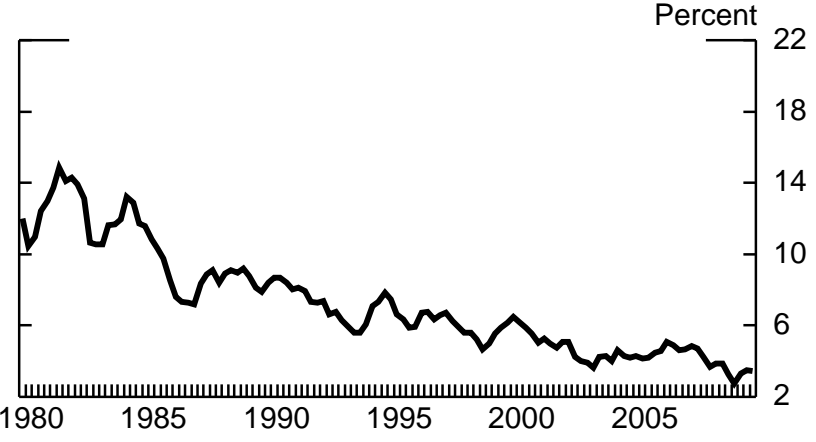

United Kingdom

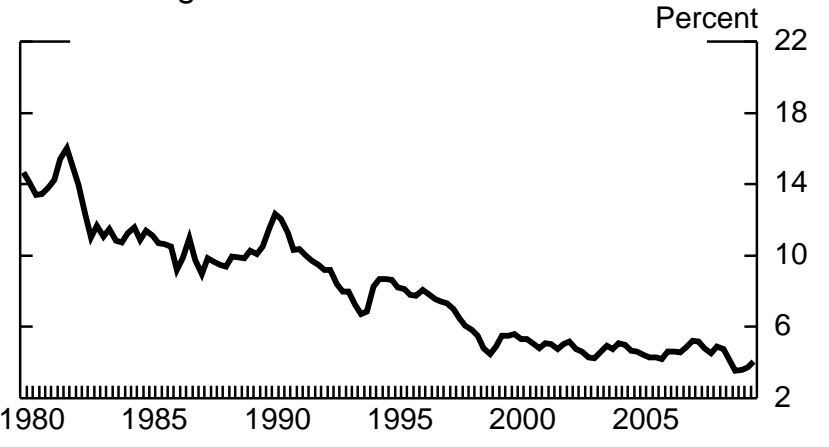

Italy

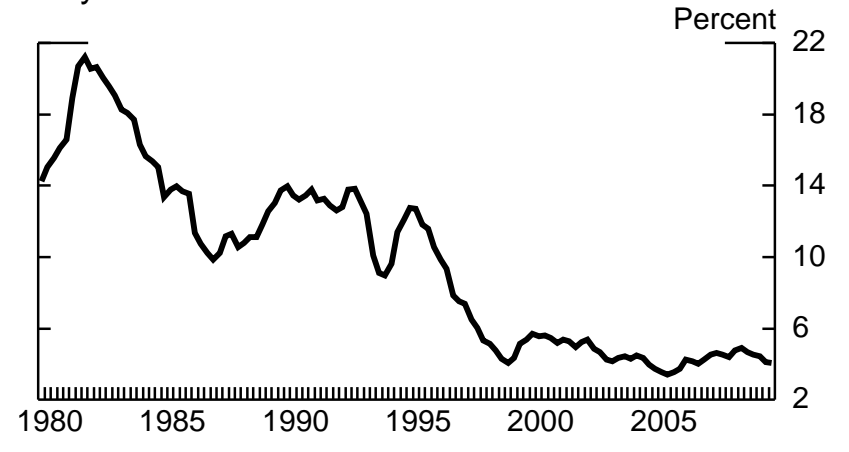

France

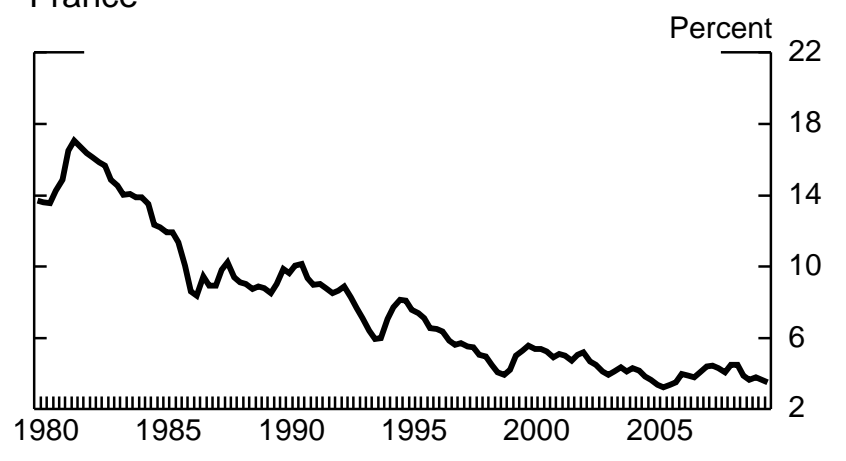

\author{
Germany
}

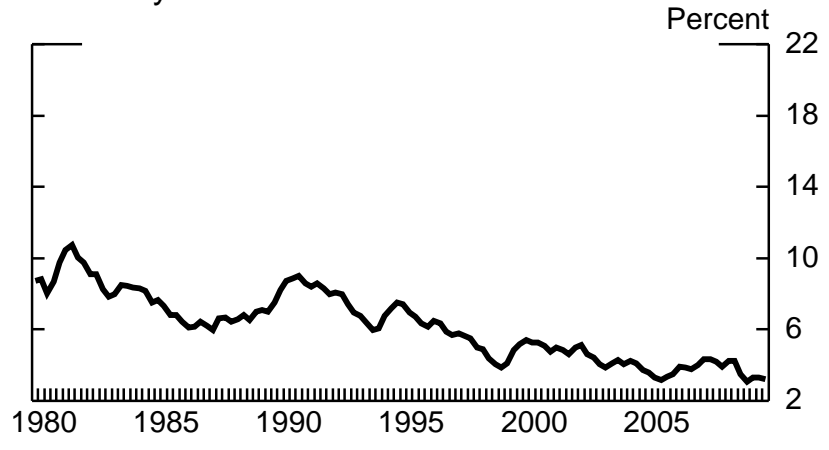

Japan

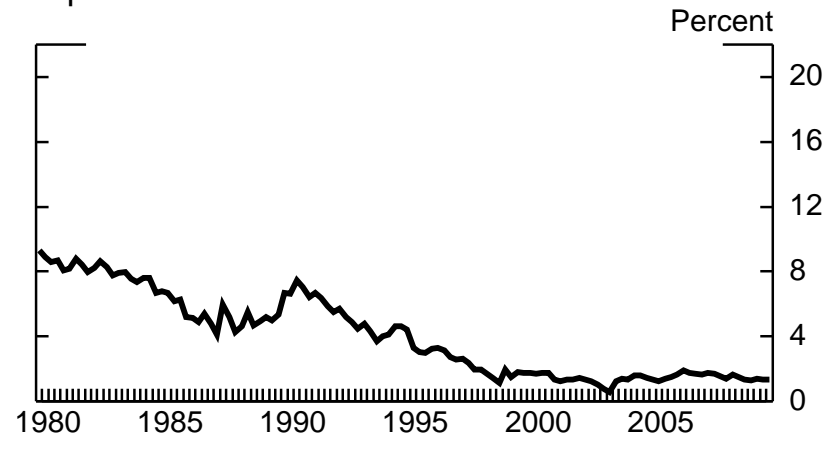

Canada

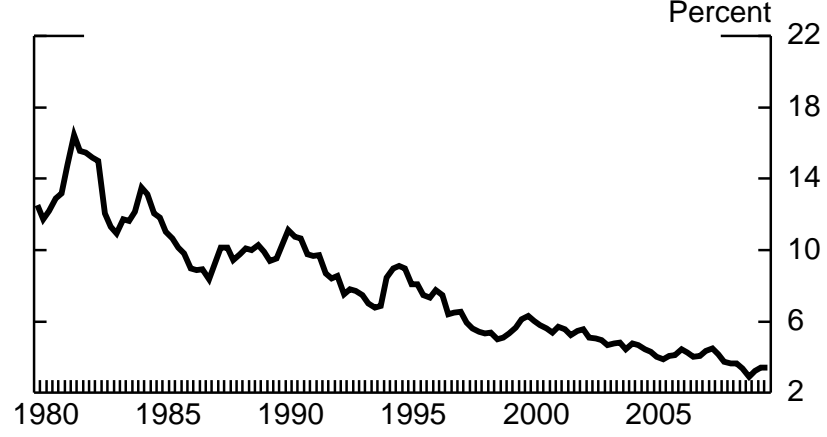




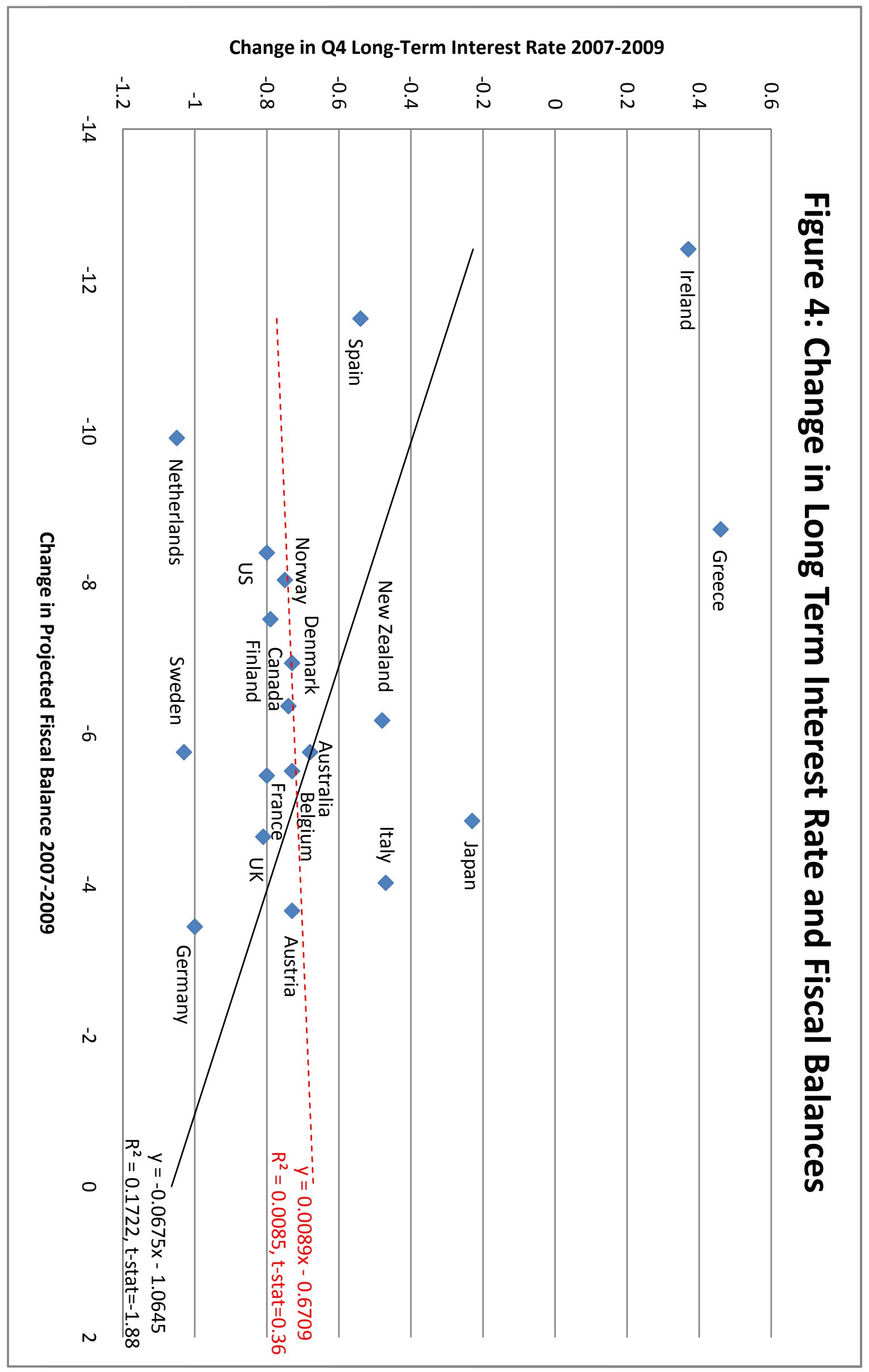




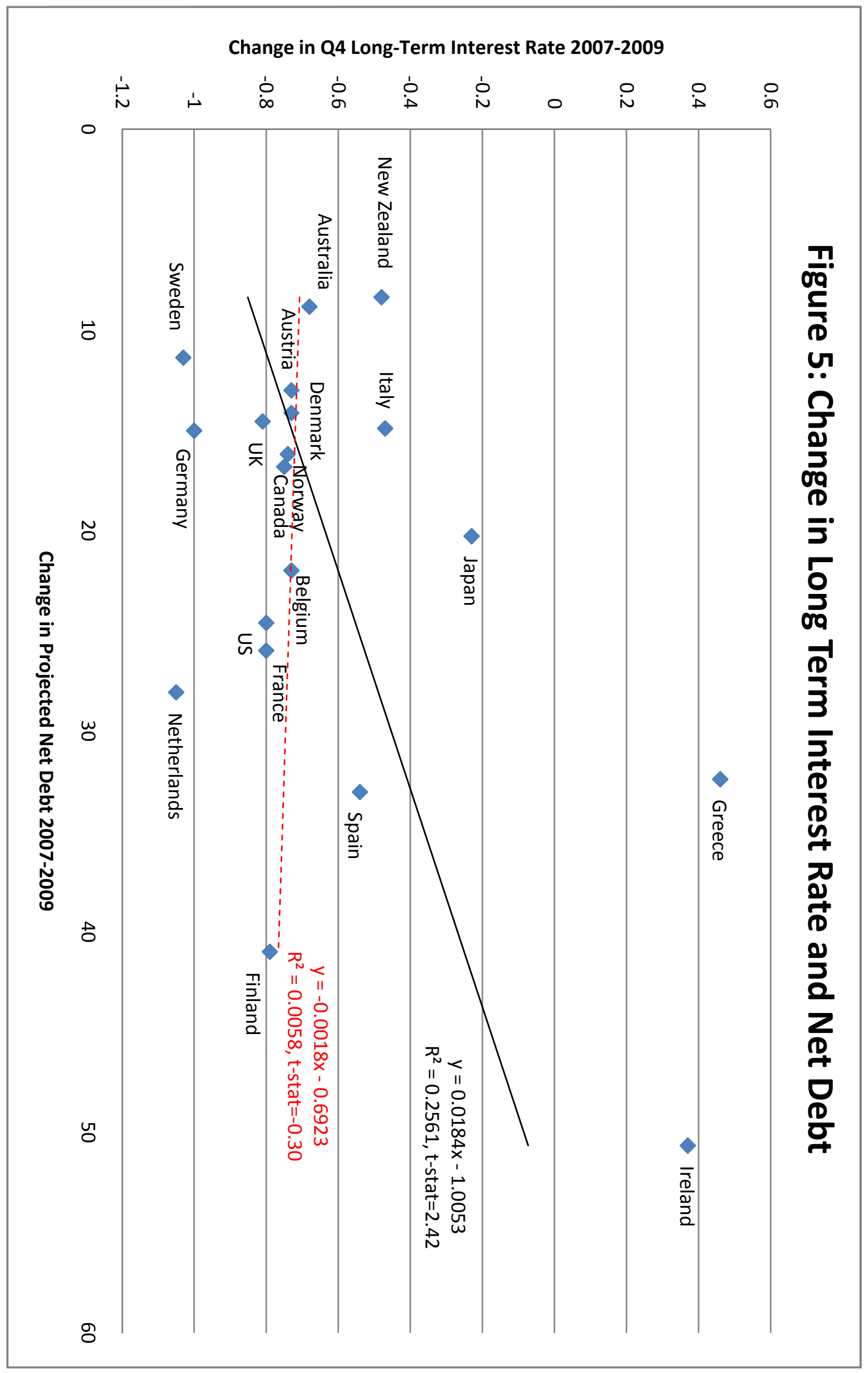




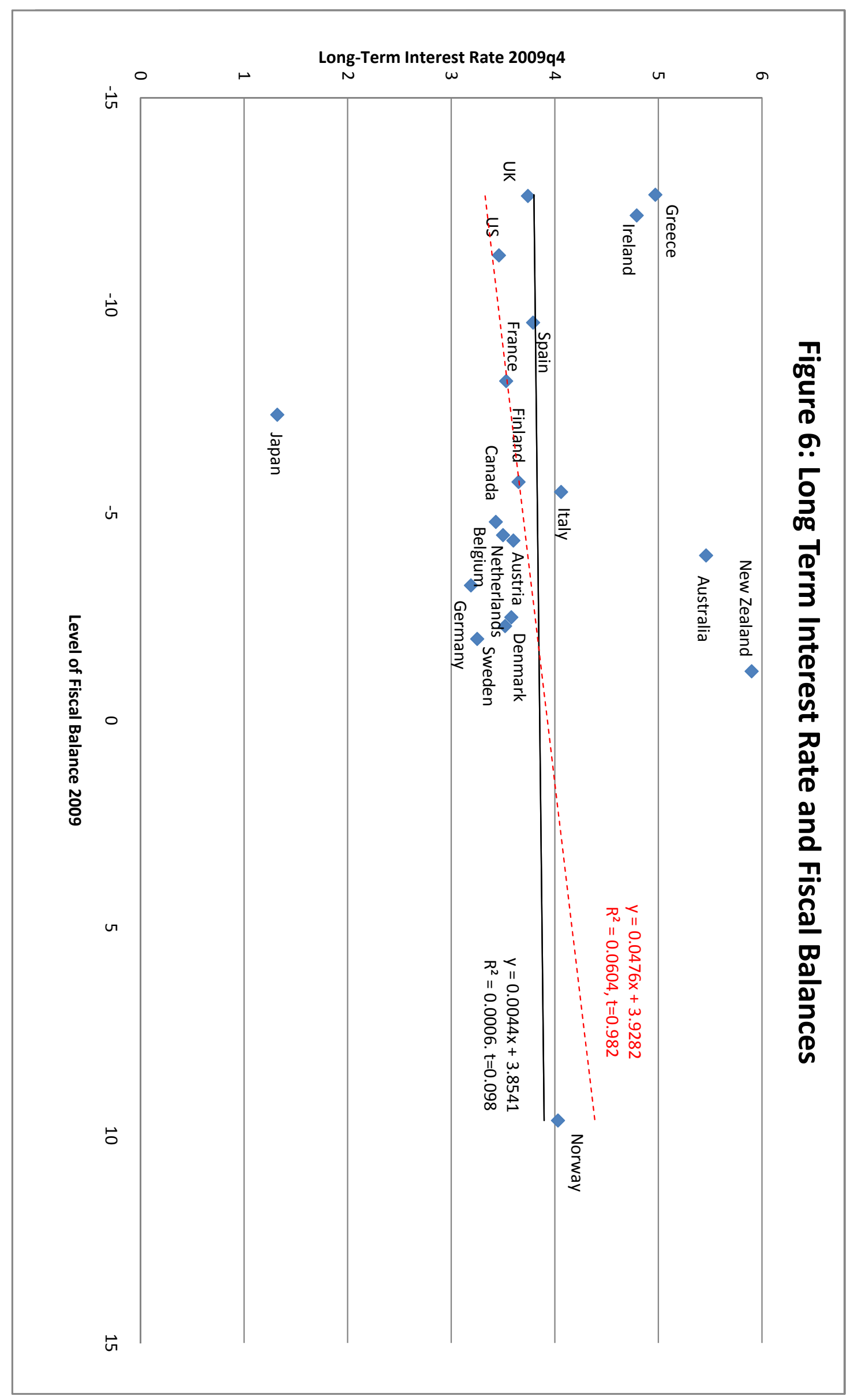




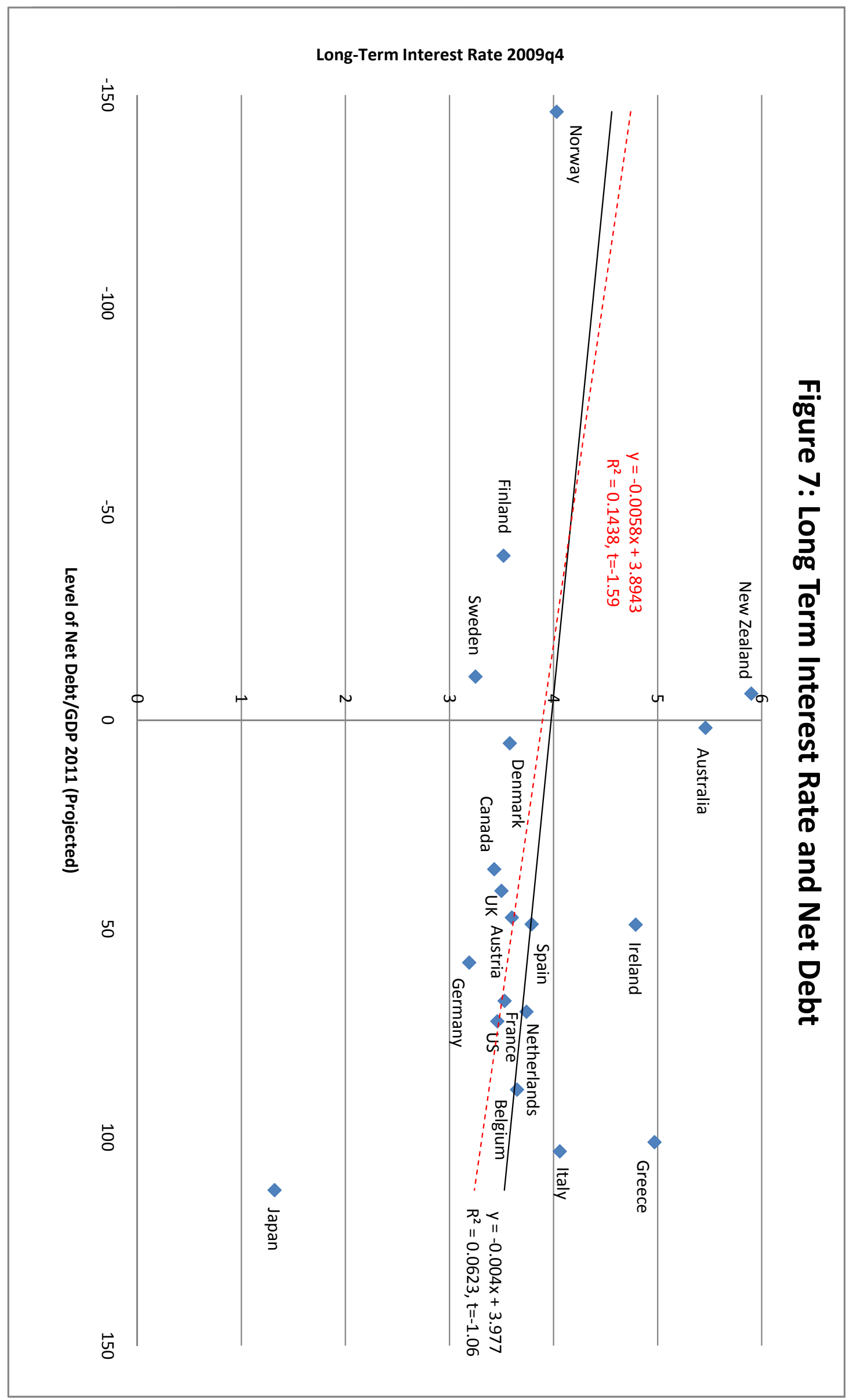




\section{Figure 8: Net Debt Dynamic Simulations for G-7 Countries}

United States

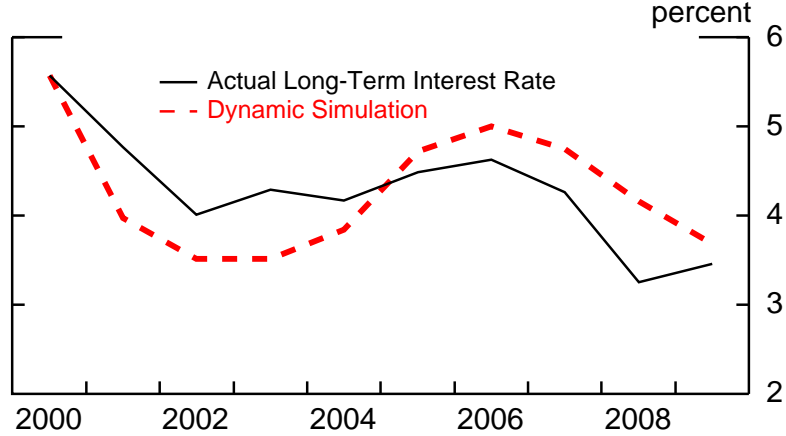

United Kingdom

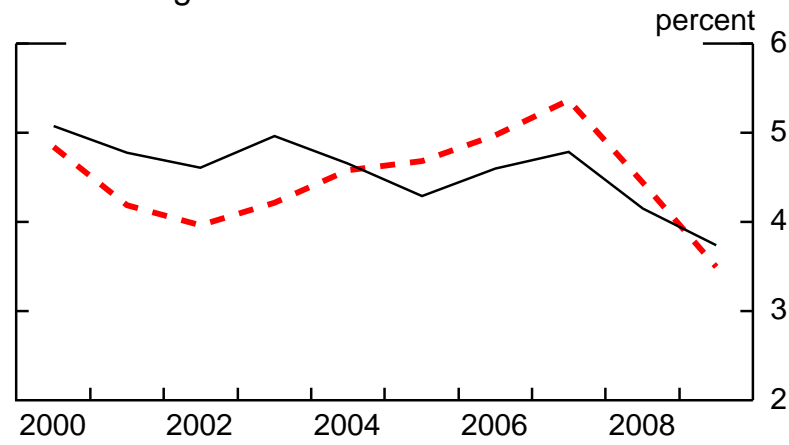

Italy

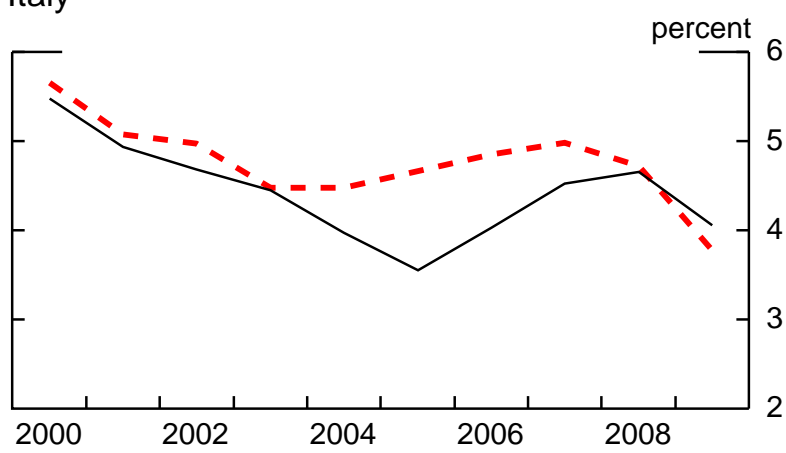

France

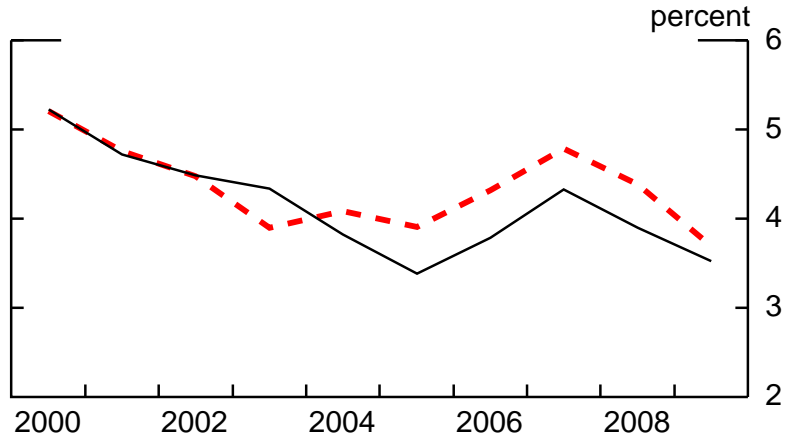

Germany

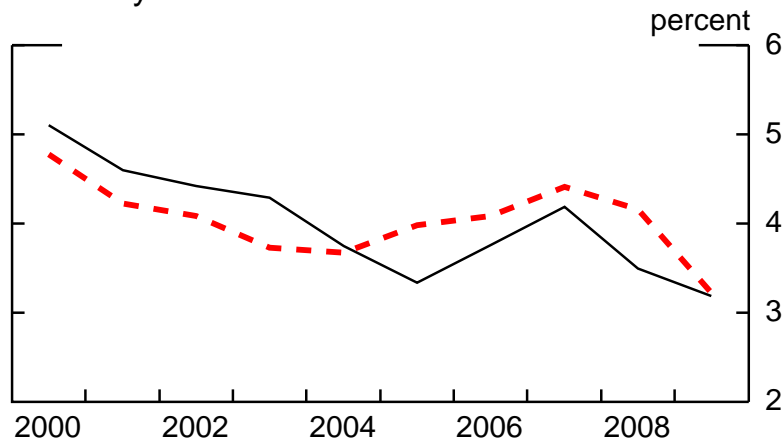

Japan

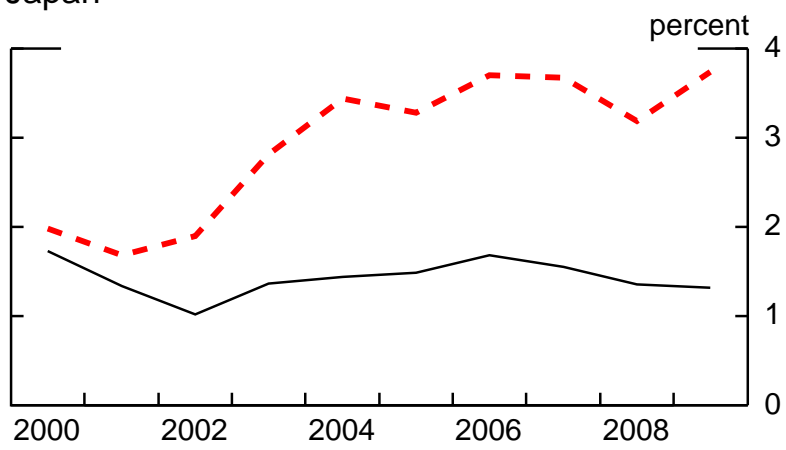

Canada

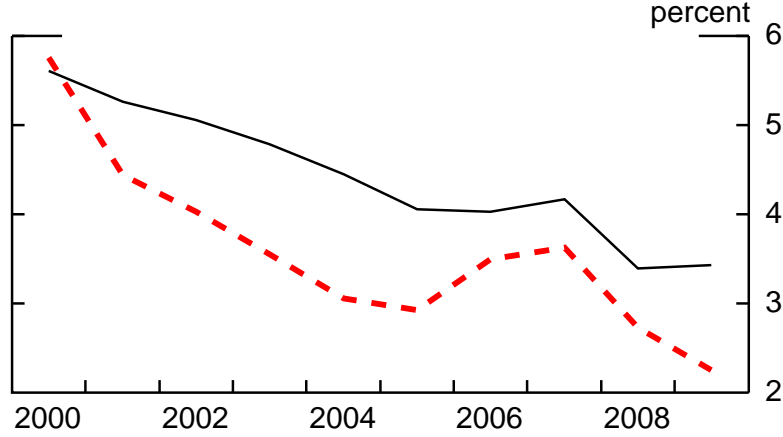


Figure 9: Structural Deficit Dynamic Simulations for G-7 Countries

United States

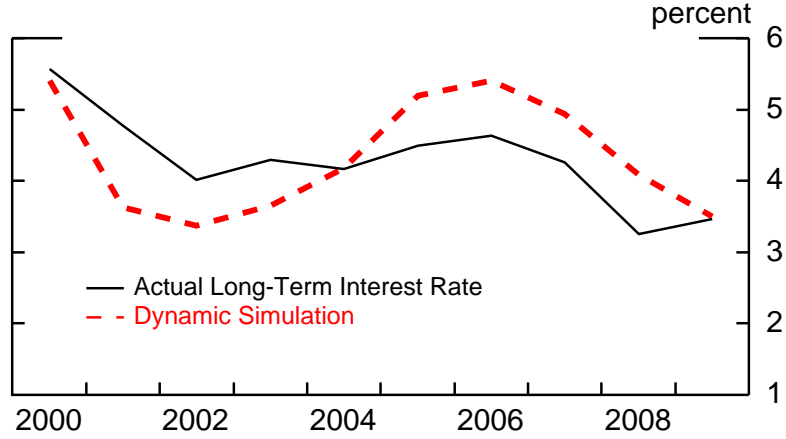

United Kingdom

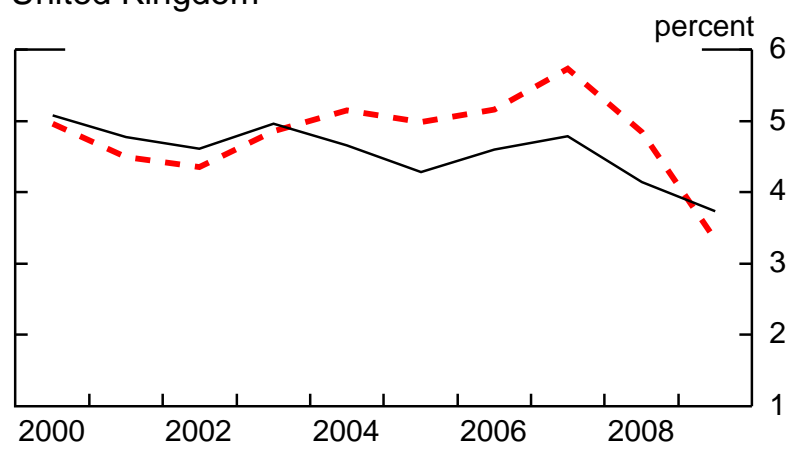

Italy

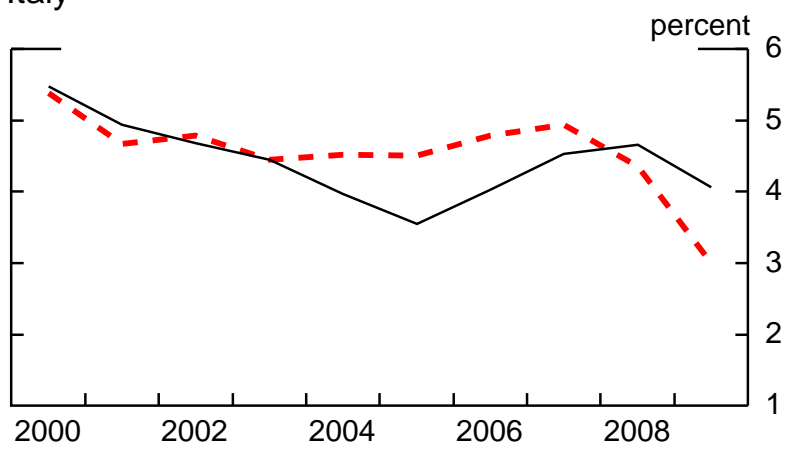

France

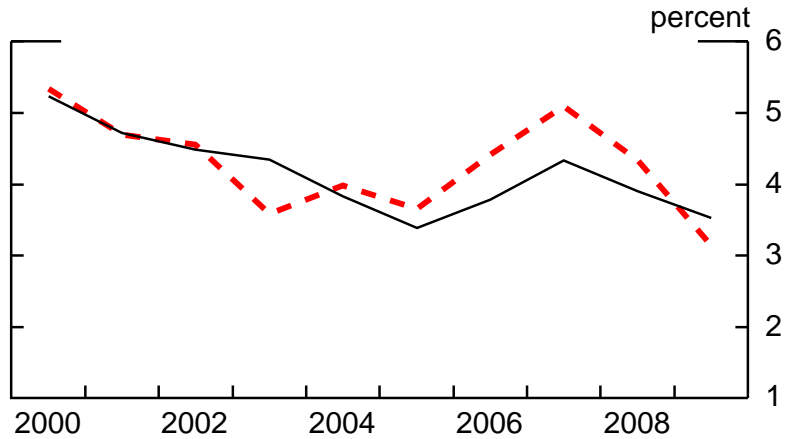

Germany

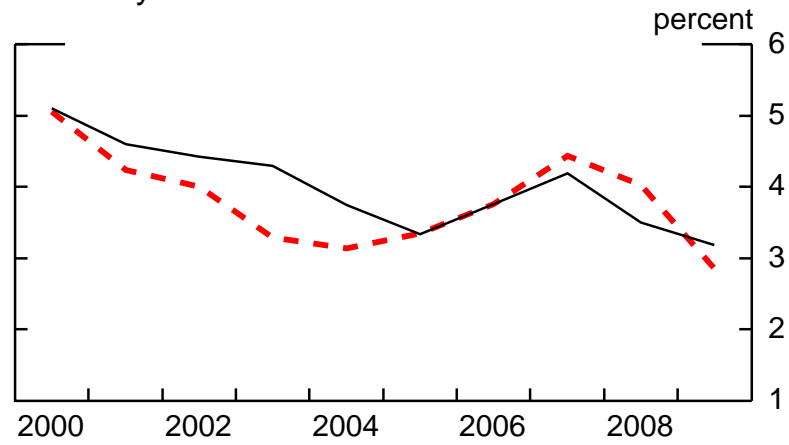

Japan

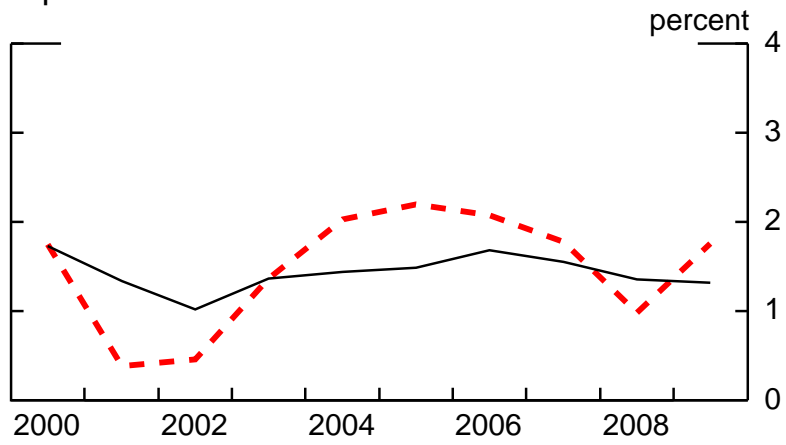

Canada

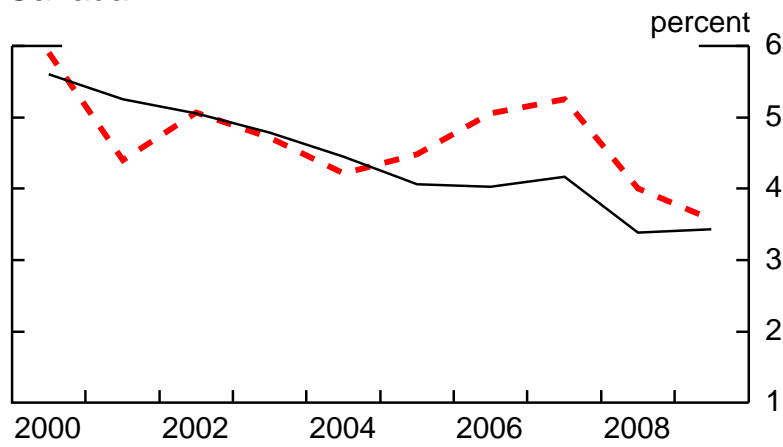


Table 1: Baseline Regressions

\begin{tabular}{|c|c|c|c|c|c|c|c|c|}
\hline & \multicolumn{4}{|c|}{ Full Panel } & \multicolumn{4}{|c|}{ G-7 Countries } \\
\hline & 1 & 2 & 3 & 4 & 5 & 6 & 7 & 8 \\
\hline \multirow[t]{2}{*}{ Short-term IR } & 0.314 & 0.317 & 0.237 & 0.276 & 0.325 & 0.317 & 0.337 & 0.314 \\
\hline & 11.015 & 9.938 & 5.663 & 8.145 & 5.849 & 6.047 & 5.150 & 4.058 \\
\hline \multirow[t]{2}{*}{ Long-term IR(lag) } & 0.379 & 0.365 & 0.445 & 0.305 & 0.369 & 0.338 & 0.379 & 0.257 \\
\hline & 8.233 & 7.244 & 7.767 & 7.025 & 3.582 & 3.293 & 3.616 & 2.922 \\
\hline \multirow[t]{2}{*}{ GDP } & 0.091 & 0.104 & 0.086 & 0.110 & 0.285 & 0.268 & 0.320 & 0.231 \\
\hline & 1.683 & 1.690 & 1.666 & 2.059 & 2.873 & 2.865 & 2.918 & 2.755 \\
\hline \multirow[t]{2}{*}{ Inflation } & 0.210 & 0.237 & 0.184 & 0.197 & 0.210 & 0.237 & 0.253 & 0.326 \\
\hline & 3.422 & 3.545 & 2.879 & 3.065 & 2.098 & 2.253 & 1.937 & 3.460 \\
\hline \multirow[t]{2}{*}{ Gross Debt } & 0.004 & & & & 0.010 & & & \\
\hline & 2.436 & & & & 3.142 & & & \\
\hline \multirow[t]{2}{*}{ Net Debt } & & 0.004 & & & & 0.012 & & \\
\hline & & 2.135 & & & & 3.376 & & \\
\hline \multirow[t]{2}{*}{ Primary Balance } & & & -0.035 & & & & -0.108 & \\
\hline & & & -2.119 & & & & -2.328 & \\
\hline \multirow[t]{2}{*}{ Structural Balance } & & & & -0.055 & & & & -0.112 \\
\hline & & & & -2.430 & & & & -2.462 \\
\hline \#Obs & 347 & 319 & 344 & 276 & 140 & 140 & 133 & 105 \\
\hline $\mathrm{R}^{\wedge} 2$ & 0.975 & 0.975 & 0.968 & 0.965 & 0.973 & 0.974 & 0.972 & 0.971 \\
\hline SER & 0.449 & 0.447 & 0.457 & 0.348 & 0.494 & 0.486 & 0.498 & 0.379 \\
\hline
\end{tabular}

First 4 columns represent entire sample. Second 4 columns represent G7 countries only. Interest rate variables are contemporaneous. All other variables are 2-year ahead forecasts.

Panel regression with unreported constant as well as period and cross-sectional fixed effects.

19 cross-sections and 20 periods (1988 - 2007).

t-statistic reported underneath coefficient

Bold indicates signifance at the 10 percent level.

G7 includes Canada, France, Germany, Italy, Japan, United States and United Kingdom 
Table 2: Contemporaneous Independent Variables

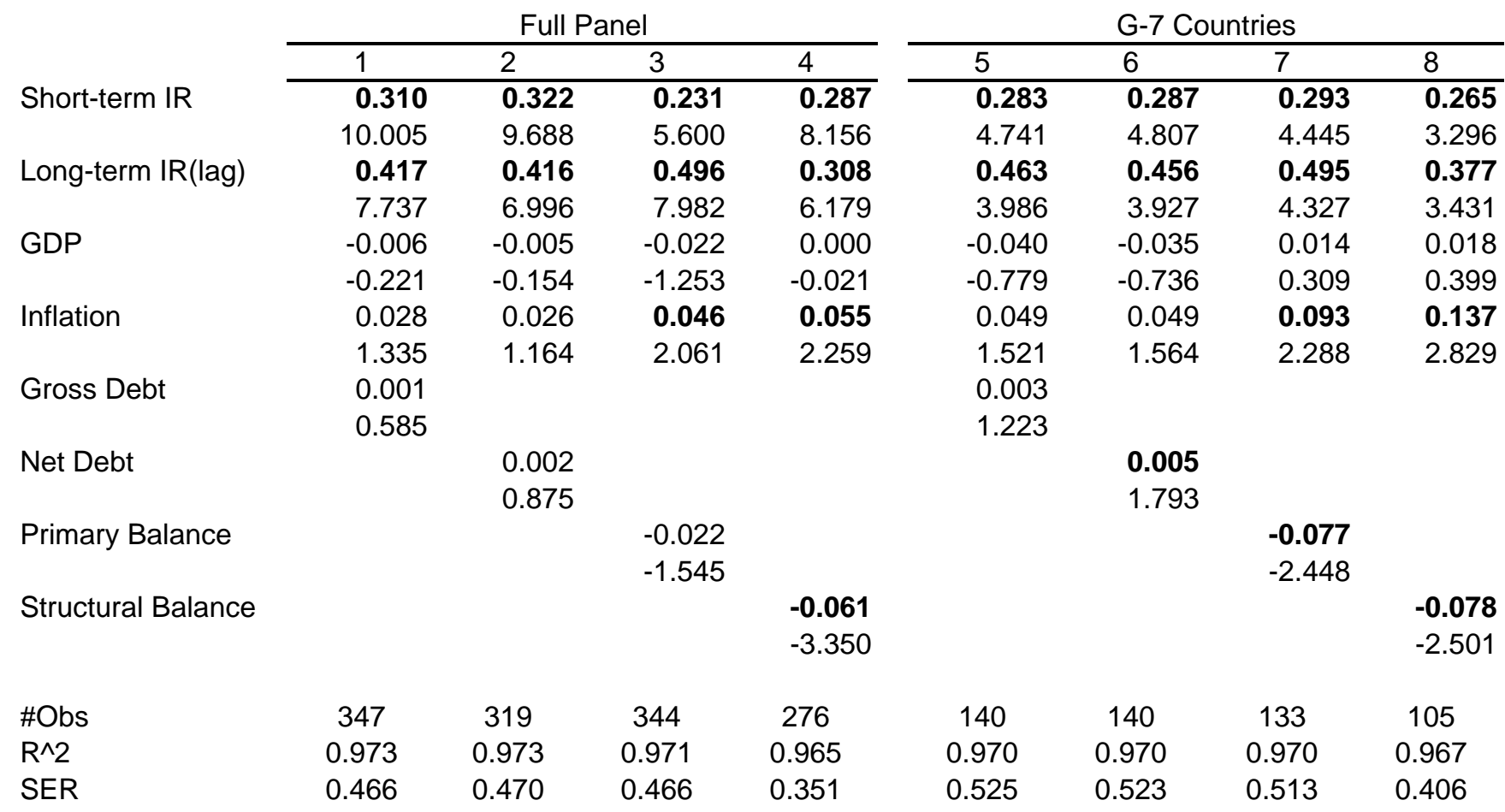

First 4 columns represent entire sample. Second 4 columns represent G7 countries only.

All variables are contemporaneous

Panel regression with unreported constant as well as period and cross-sectional fixed effects.

19 cross-sections and 20 periods (1988 - 2007).

t-statistic reported underneath coefficient

Bold indicates signifance at the 10 percent level.

G7 includes Canada, France, Germany, Italy, Japan, United States and United Kingdom 
Table 3: 5-year 5-year Forward Interest Rates

\begin{tabular}{|c|c|c|c|c|c|c|c|c|}
\hline & & Countri & 0-year & & & Countri & orward F & \\
\hline & 1 & 2 & 3 & 4 & 5 & 6 & 7 & 8 \\
\hline Short-term IR & 0.238 & 0.235 & 0.224 & 0.187 & 0.048 & 0.040 & 0.080 & 0.100 \\
\hline & 5.567 & 5.726 & 4.804 & 3.526 & 0.907 & 0.792 & 1.526 & 1.074 \\
\hline Long-term IR(lag) & 0.383 & 0.361 & 0.379 & 0.464 & 0.560 & 0.540 & 0.621 & 0.513 \\
\hline & 5.160 & 4.900 & 4.747 & 4.265 & 5.845 & 5.588 & 5.659 & 4.100 \\
\hline GDP & 0.174 & 0.162 & 0.159 & 0.107 & 0.122 & 0.116 & 0.169 & 0.251 \\
\hline & 3.215 & 3.080 & 2.718 & 1.747 & 1.284 & 1.290 & 1.577 & 1.741 \\
\hline Inflation & 0.063 & 0.083 & 0.040 & 0.184 & 0.112 & 0.127 & 0.126 & 0.069 \\
\hline & 1.105 & 1.375 & 0.692 & 2.682 & 1.206 & 1.385 & 1.310 & 0.454 \\
\hline Gross Debt & 0.005 & & & & 0.005 & & & \\
\hline & 2.947 & & & & 1.517 & & & \\
\hline Net Debt & & 0.006 & & & & 0.006 & & \\
\hline & & 3.040 & & & & 1.564 & & \\
\hline Primary Balance & & & -0.028 & & & & -0.060 & \\
\hline & & & -1.428 & & & & -1.472 & \\
\hline Structural Balance & & & & -0.069 & & & & -0.083 \\
\hline & & & & -2.234 & & & & -1.538 \\
\hline \#Obs & 95 & 95 & 90 & 70 & 95 & 95 & 90 & 70 \\
\hline$R^{\wedge} 2$ & 0.989 & 0.989 & 0.988 & 0.984 & 0.957 & 0.958 & 0.959 & 0.949 \\
\hline SER & 0.291 & 0.289 & 0.299 & 0.281 & 0.510 & 0.508 & 0.500 & 0.515 \\
\hline
\end{tabular}

Interest rate variables are contemporaneous. All other variables are 2-year ahead forecasts.

Panel regression with unreported constant as well as period and cross-sectional fixed effects.

5 cross-sections and 19 periods (1988 - 2006).

t-statistic reported underneath coefficient

Bold indicates signifance at the 10 percent level.

G5 include Canada, Germany, Japan, United States and United Kingdom 
Table 4: Removing Inflation

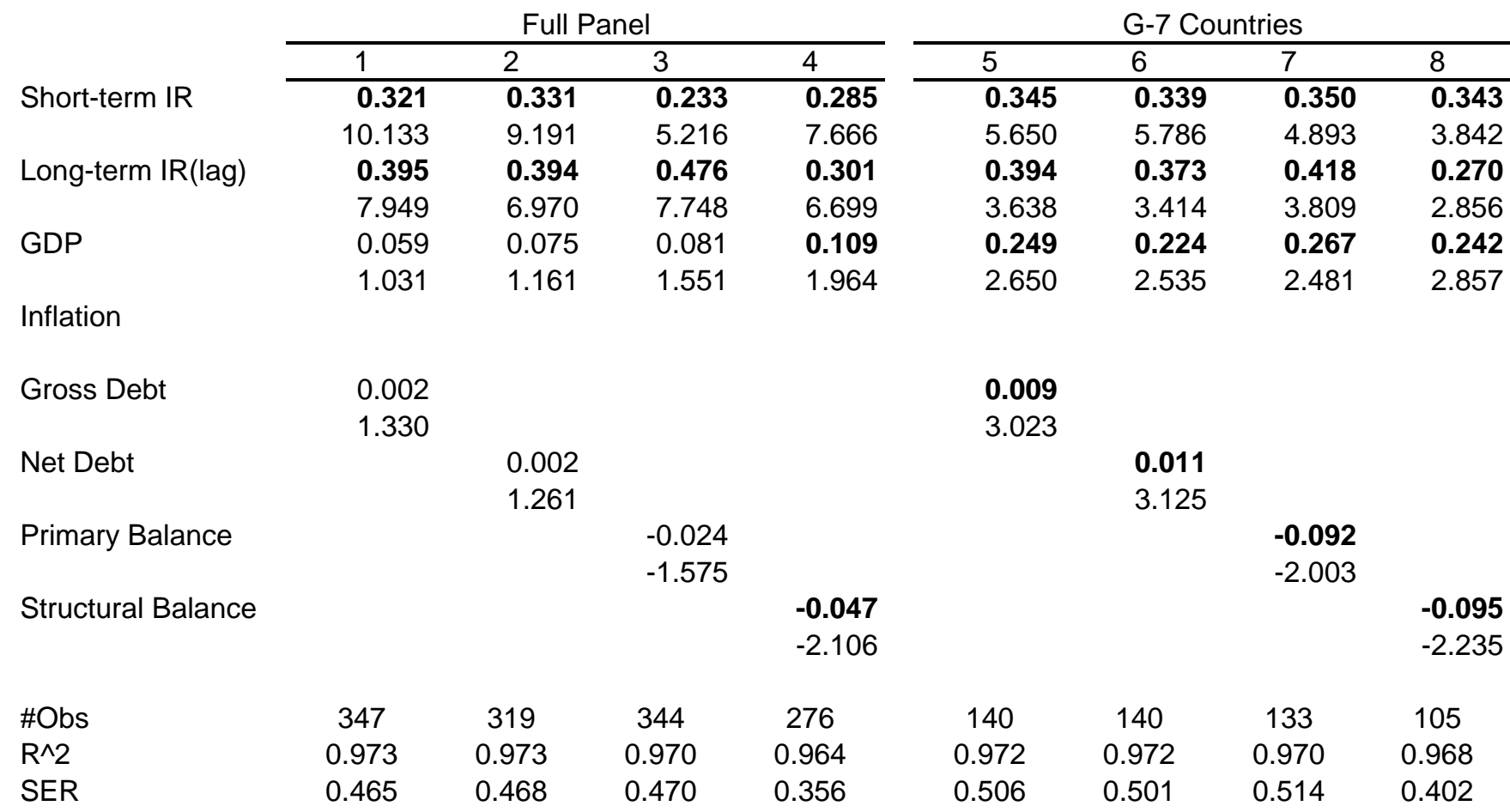

First 4 columns represent entire sample. Second 4 columns represent $G 7$ countries only. Interest rate variables are contemporaneous. All other variables are 2-year ahead forecasts. Panel regression with unreported constant as well as period and cross-sectional fixed effects. 19 cross-sections and 20 periods (1988 - 2007).

t-statistic reported underneath coefficient

Bold indicates signifance at the 10 percent level.

G7 includes Canada, France, Germany, Italy, Japan, United States and United Kingdom 
Table 5: Projected Inflation as Dependent Variable

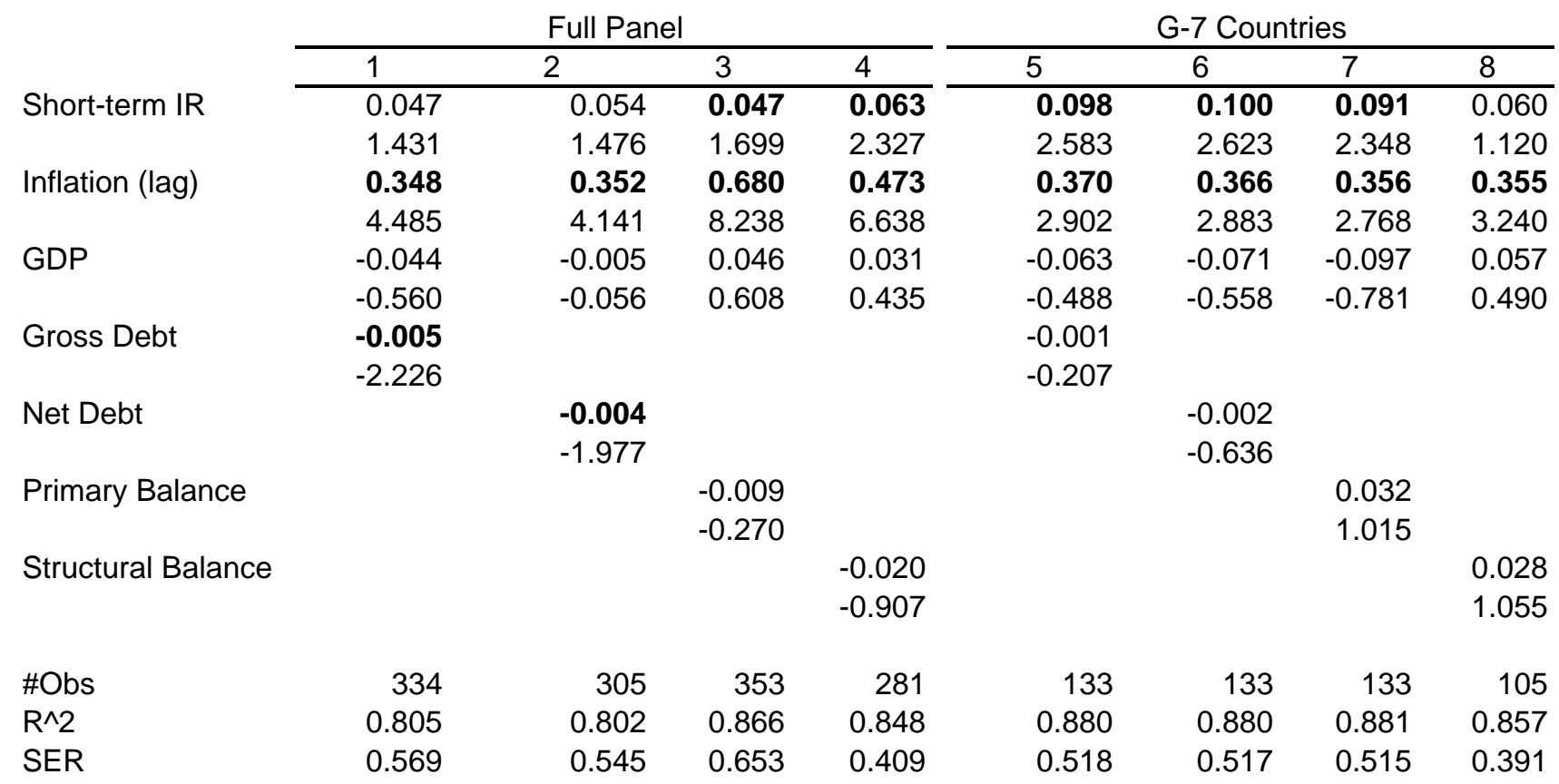

First 4 columns represent entire sample. Second 4 columns represent G7 countries only. Interest rate variables are contemporaneous. All other variables are 2-year ahead forecasts.

Panel regression with unreported constant as well as period and cross-sectional fixed effects.

19 cross-sections and 19 periods (1989 - 2007).

t-statistic reported underneath coefficient

Bold indicates signifance at the 10 percent level.

G7 includes Canada, France, Germany, Italy, Japan, United States and United Kingdom 
Table 6: Removing GDP and the Short IR

\begin{tabular}{|c|c|c|c|c|c|c|c|c|}
\hline & \multicolumn{4}{|c|}{ Full Panel } & \multicolumn{4}{|c|}{ G-7 Countries } \\
\hline & 1 & 2 & 3 & 4 & 5 & 6 & 7 & 8 \\
\hline \multicolumn{9}{|l|}{ Short-term IR } \\
\hline \multirow[t]{2}{*}{ Long-term IR(lag) } & 0.671 & 0.642 & 0.680 & 0.564 & 0.677 & 0.646 & 0.690 & 0.529 \\
\hline & 13.783 & 11.176 & 13.802 & 9.948 & 6.044 & 5.691 & 5.915 & 4.777 \\
\hline \multicolumn{9}{|l|}{ GDP } \\
\hline \multirow[t]{2}{*}{ Inflation } & 0.255 & 0.303 & 0.163 & 0.249 & 0.291 & 0.309 & 0.281 & 0.407 \\
\hline & 3.083 & 3.266 & 2.329 & 3.142 & 2.084 & 2.147 & 1.719 & 3.156 \\
\hline \multirow[t]{2}{*}{ Gross Debt } & 0.001 & & & & 0.003 & & & \\
\hline & 0.749 & & & & 1.366 & & & \\
\hline \multirow{2}{*}{ Net Debt } & & 0.004 & & & & 0.007 & & \\
\hline & & 1.941 & & & & 2.171 & & \\
\hline \multirow[t]{2}{*}{ Primary Balance } & & & -0.014 & & & & -0.041 & \\
\hline & & & -0.740 & & & & -0.860 & \\
\hline \multirow[t]{2}{*}{ Structural Balance } & & & & -0.049 & & & & -0.103 \\
\hline & & & & -1.866 & & & & -1.943 \\
\hline \#Obs & 347 & 319 & 344 & 276 & 140 & 140 & 133 & 105 \\
\hline$R^{\wedge} 2$ & 0.960 & 0.960 & 0.959 & 0.951 & 0.961 & 0.962 & 0.959 & 0.960 \\
\hline SER & 0.567 & 0.564 & 0.551 & 0.414 & 0.592 & 0.584 & 0.600 & 0.441 \\
\hline
\end{tabular}

First 4 columns represent entire sample. Second 4 columns represent G7 countries only. Interest rate variables are contemporaneous. All other variables are 2-year ahead forecasts. Panel regression with unreported constant as well as period and cross-sectional fixed effects. 19 cross-sections and 20 periods (1988 - 2007).

t-statistic reported underneath coefficient Bold indicates signifance at the 10 percent level.

G7 includes Canada, France, Germany, Italy, Japan, United States and United Kingdom 
Table 7: Exploring Non-Linearities

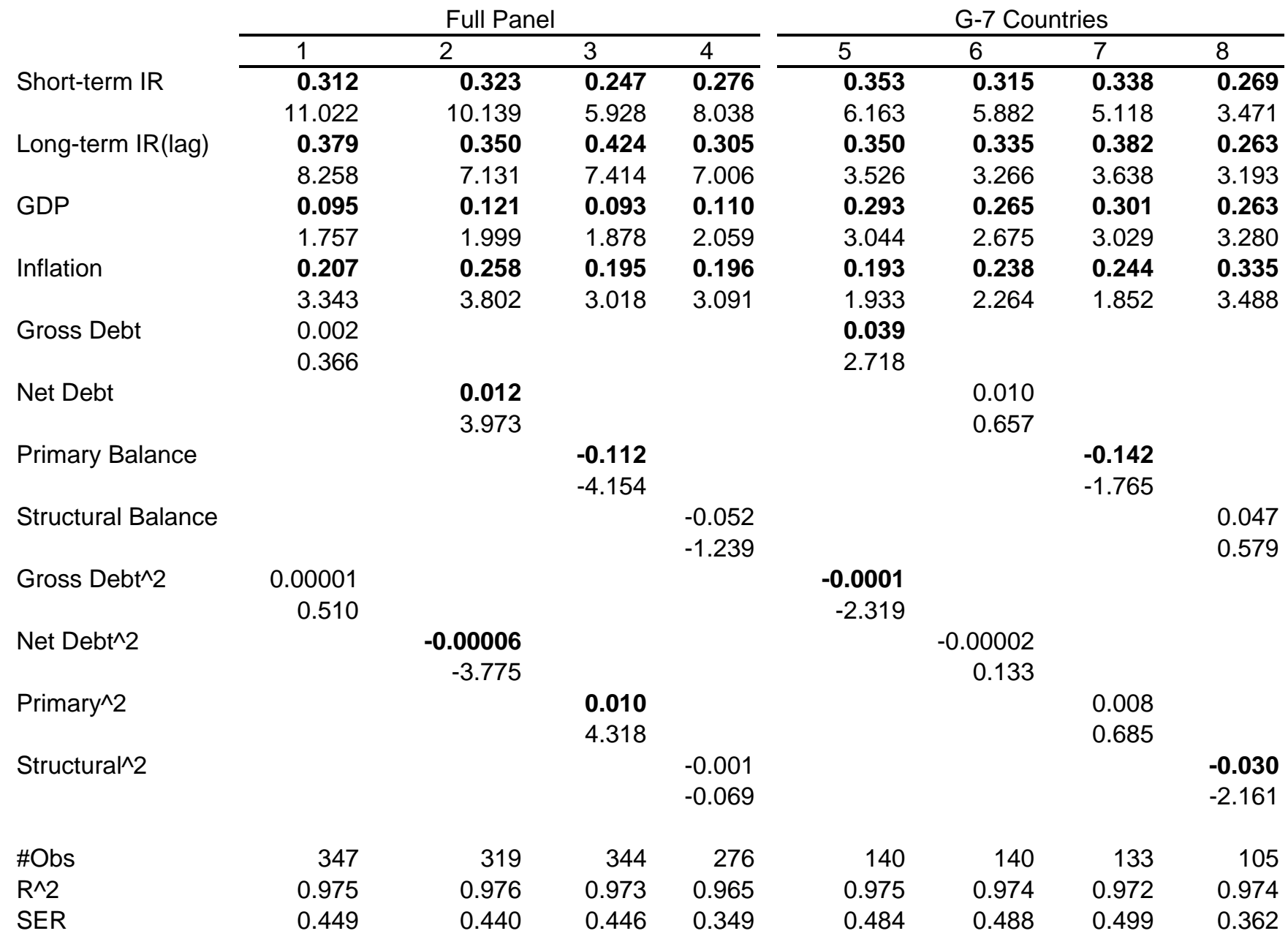

First 4 columns represent entire sample. Second 4 columns represent $G 7$ countries only. Interest rate variables are contemporaneous. All other variables are 2-year ahead forecasts.

Panel regression with unreported constant as well as period and cross-sectional fixed effects. 19 cross-sections and 20 periods (1988 - 2007).

t-statistic reported underneath coefficient

Bold indicates signifance at the 10 percent level.

G7 includes Canada, France, Germany, Italy, Japan, United States and United Kingdom 
Table 8: Time Series Regressions - Net Debt

Short-term IR

\begin{tabular}{rrrrrrr}
\multicolumn{1}{c}{ Canada } & \multicolumn{1}{c}{ France } & \multicolumn{1}{c}{ Germany } & \multicolumn{1}{l}{ Italy } & \multicolumn{1}{l}{ Japan } & \multicolumn{1}{c}{ UK } & \multicolumn{1}{c}{ US } \\
\hline $\mathbf{0 . 3 6 8}$ & 0.089 & 0.136 & $\mathbf{0 . 6 6 6}$ & $\mathbf{0 . 4 7 7}$ & $\mathbf{0 . 3 7 1}$ & $\mathbf{0 . 3 1 3}$ \\
2.071 & 1.125 & 1.382 & 4.486 & 8.160 & 3.560 & 2.212 \\
-0.066 & -0.058 & -0.110 & -0.004 & $\mathbf{0 . 2 2 8}$ & -0.051 & $\mathbf{- 0 . 4 1 6}$ \\
-0.176 & -0.244 & -0.804 & -0.039 & 1.766 & -0.240 & -2.072 \\
0.355 & 0.470 & $\mathbf{0 . 8 5 0}$ & $\mathbf{1 . 6 7 7}$ & $\mathbf{0 . 4 9 8}$ & $\mathbf{1 . 3 6 9}$ & 0.405 \\
0.496 & 0.694 & 3.505 & 3.393 & 1.810 & 4.336 & 1.302 \\
-0.083 & 0.407 & $\mathbf{1 . 0 1 7}$ & $\mathbf{0 . 9 6 6}$ & -0.254 & 0.468 & $\mathbf{0 . 4 2 0}$ \\
-0.355 & 0.849 & 3.872 & 3.429 & -1.065 & 1.328 & 2.025
\end{tabular}

Gross Debt

Net Debt

$\begin{array}{ll}-0.001 & -0.088\end{array}$

0.019

0.066

$-0.014$

0.016

0.022

Primary Balance

$$
-0.058
$$

$-2.399$

1.185

2.584

$-1.799$

0.869

0.808

Structural Balance

Time Trend

$$
-0.222
$$

$-0.182$

$-0.109$

0.135

0.073

$-0.168$

$-0.236$

$-2.308$

$-1.943$

1.523

1.372

$-2.341$

$-4.122$

\#Obs

$\mathrm{R}^{\wedge} 2$

20

20

20

SER

0.925

0.945

0.951

20

20

0.972

20

20

0.702

0.595

0.445

0.982

0.637

0.373

0.961

0.548

0.942

0.446

Interest rate variables are contemporaneous. All other variables are 2-year ahead forecasts.

20 periods (1988 - 2007).

t-statistic reported underneath coefficient

Bold indicates signifance at the 10 percent level. 
Table 9: Time Series Regressions - Structural Balance

\begin{tabular}{lrrrrrrr} 
& \multicolumn{1}{c}{ Canada } & \multicolumn{1}{c}{ France } & \multicolumn{1}{c}{ Germany } & \multicolumn{1}{c}{ Italy } & \multicolumn{1}{c}{ Japan } & \multicolumn{1}{c}{ UK } & \multicolumn{1}{c}{ US } \\
\cline { 2 - 7 } Short-term IR & 0.204 & 0.263 & 0.165 & $\mathbf{0 . 7 2 8}$ & $\mathbf{0 . 8 0 7}$ & 0.647 & 0.320 \\
& 1.630 & 1.185 & 1.021 & 3.245 & 4.393 & $\mathbf{3 . 1 2 4}$ & 1.282 \\
Long-term IR(lag) & -0.204 & -0.091 & -0.152 & -0.118 & 0.209 & -0.145 & $\mathbf{- 0 . 4 2 9}$ \\
& -0.723 & -0.288 & -0.621 & -0.414 & 1.349 & -0.446 & -2.139 \\
GDP & 0.316 & 0.856 & $\mathbf{0 . 7 7 9}$ & 1.324 & $\mathbf{0 . 5 4 6}$ & $\mathbf{1 . 8 8 6}$ & 0.245 \\
& 0.396 & 1.061 & 2.524 & 1.212 & 3.068 & 5.355 & 0.810 \\
Inflation & -0.063 & 0.485 & $\mathbf{0 . 9 6 1}$ & 0.720 & -0.037 & -0.264 & 0.365 \\
& -0.201 & 0.763 & 1.963 & 0.620 & -0.191 & -0.349 & 0.653
\end{tabular}

Gross Debt

Net Debt

Primary Balance

$\begin{array}{lccccccc}\text { Structural Balance } & -0.306 & -\mathbf{- 0 . 5 6 5} & -0.283 & -0.310 & -0.097 & -0.043 & -0.046 \\ & -1.634 & -2.032 & -0.636 & -1.454 & -1.590 & -0.319 & -0.390 \\ \text { Time Trend } & -\mathbf{0 . 2 4 0} & -0.174 & -0.102 & -0.020 & -0.035 & -\mathbf{0 . 2 2 6} & \mathbf{- 0 . 2 1 7} \\ & -3.040 & -1.354 & -1.421 & -0.069 & -0.811 & -2.385 & -3.056 \\ & & & & & & & \\ \text { \#Obs } & 15 & 15 & 15 & 15 & 15 & 15 & 15 \\ \text { R^2 } & 0.900 & 0.846 & 0.895 & 0.964 & 0.947 & 0.930 & 0.883 \\ \text { SER } & 0.587 & 0.673 & 0.492 & 0.694 & 0.314 & 0.488 & 0.483\end{array}$

Interest rate variables are contemporaneous. All other variables are 2-year ahead forecasts.

15 periods (1993 - 2007).

t-statistic reported underneath coefficient

Bold indicates signifance at the 10 percent level. 
Table 10: Impact of the Debts and Deficits of Others

\begin{tabular}{|c|c|c|c|c|c|c|c|c|}
\hline & \multicolumn{4}{|c|}{ Full Panel } & \multicolumn{4}{|c|}{ G-7 Countries } \\
\hline & 1 & 2 & 3 & 4 & 5 & 6 & 7 & 8 \\
\hline \multirow[t]{2}{*}{ Short-term IR } & 0.387 & 0.375 & 0.328 & 0.488 & 0.388 & 0.361 & 0.380 & 0.512 \\
\hline & 11.665 & 9.867 & 8.215 & 9.863 & 6.919 & 6.420 & 6.518 & 6.372 \\
\hline \multirow[t]{2}{*}{ Long-term IR(lag) } & 0.339 & 0.304 & 0.378 & 0.150 & 0.339 & 0.326 & 0.331 & 0.155 \\
\hline & 9.431 & 7.516 & 9.687 & 3.387 & 5.672 & 5.344 & 5.603 & 2.156 \\
\hline \multirow[t]{2}{*}{ GDP } & 0.389 & 0.402 & 0.330 & 0.544 & 0.602 & 0.573 & 0.585 & 0.608 \\
\hline & 4.230 & 4.236 & 3.793 & 5.742 & 3.943 & 3.868 & 4.096 & 4.313 \\
\hline \multirow[t]{2}{*}{ Inflation } & 0.406 & 0.403 & 0.394 & 0.351 & 0.328 & 0.359 & 0.322 & 0.309 \\
\hline & 5.163 & 4.907 & 4.792 & 3.174 & 2.541 & 2.758 & 2.320 & 1.890 \\
\hline \multirow[t]{2}{*}{ Gross Debt } & 0.011 & & & & 0.012 & & & \\
\hline & 3.104 & & & & 2.634 & & & \\
\hline \multirow[t]{2}{*}{ Net Debt } & & 0.010 & & & & 0.013 & & \\
\hline & & 3.170 & & & & 2.554 & & \\
\hline \multirow{2}{*}{ Primary Balance } & & & -0.075 & & & & -0.117 & \\
\hline & & & -2.862 & & & & -3.025 & \\
\hline \multirow[t]{2}{*}{ Structural Balance } & & & & -0.125 & & & & -0.167 \\
\hline & & & & -3.325 & & & & -3.333 \\
\hline \multirow[t]{2}{*}{ Foreign Gross } & -0.003 & & & & -0.006 & & & \\
\hline & -0.491 & & & & -0.581 & & & \\
\hline \multirow[t]{2}{*}{ Foreign Net } & & -0.018 & & & & -0.015 & & \\
\hline & & -1.778 & & & & -1.044 & & \\
\hline \multirow{2}{*}{ Foreign Primary } & & & 0.107 & & & & 0.087 & \\
\hline & & & 3.018 & & & & 1.766 & \\
\hline \multirow[t]{2}{*}{ Foreign Structural } & & & & -0.546 & & & & -0.482 \\
\hline & & & & -6.943 & & & & -5.001 \\
\hline \#Obs & 347 & 319 & 344 & 276 & 140 & 140 & 133 & 105 \\
\hline $\mathrm{R}^{\wedge} 2$ & 0.920 & 0.920 & 0.904 & 0.859 & 0.929 & 0.931 & 0.925 & 0.907 \\
\hline SER & 0.777 & 0.779 & 0.822 & 0.684 & 0.745 & 0.738 & 0.759 & 0.635 \\
\hline
\end{tabular}

First 4 columns represent entire sample. Second 4 columns represent $G 7$ countries only. Interest rate variables are contemporaneous. All other variables are 2-year ahead forecasts.

Panel regression with unreported constant as well as cross-sectional fixed effects.

19 cross-sections and 20 periods (1988 - 2007).

t-statistic reported underneath coefficient

Bold indicates signifance at the 10 percent level.

G7 includes Canada, France, Germany, Italy, Japan, United States and United Kingdom 
Table 11: Baseline Regressions Pairing Combined Debts and Deficits

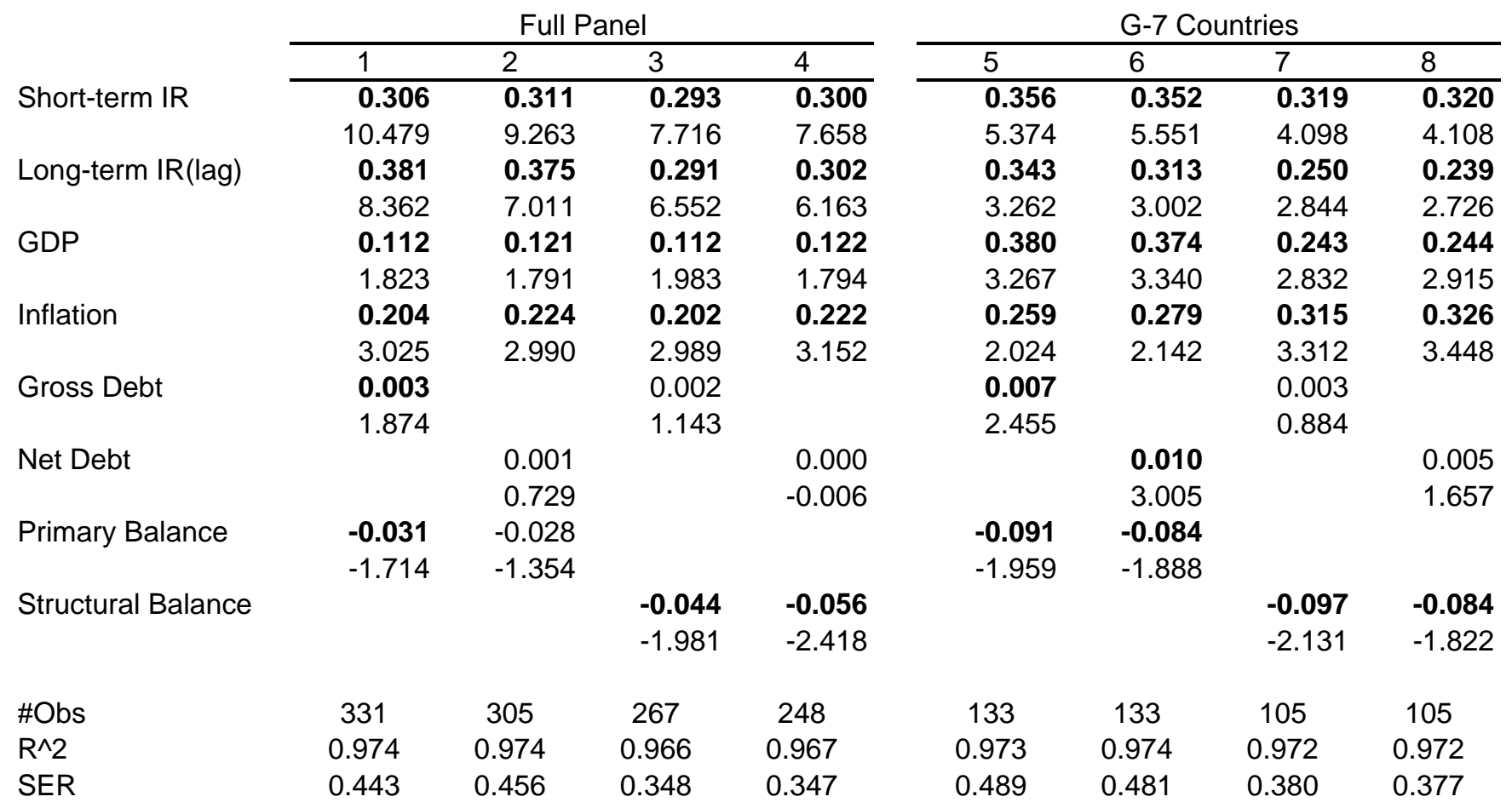

First 4 columns represent entire sample. Second 4 columns represent $\mathrm{G} 7$ countries only. Interest rate variables are contemporaneous. All other variables are 2-year ahead forecasts.

Panel regression with unreported constant as well as period and cross-sectional fixed effects.

19 cross-sections and 20 periods (1988 - 2007).

t-statistic reported underneath coefficient

Bold indicates signifance at the 10 percent level.

G7 includes Canada, France, Germany, Italy, Japan, United States and United Kingdom 
Table 12: Marginal Impact of Fiscal Variables

Estimated Change in Bond Yields

\begin{tabular}{|c|c|c|c|c|}
\hline Country & $\begin{array}{c}\text { Change in Net } \\
\text { Debt (\% of GDP)* } \\
2007-2015\end{array}$ & $\begin{array}{c}\text { Change in Structural } \\
\text { Balance (\% of GDP)* } \\
2007-2015\end{array}$ & Net Debt \& & $\begin{array}{l}\text { Structural Balance } \\
\text { Model }\end{array}$ \\
\hline & & & \multicolumn{2}{|c|}{ (Effects are measured in basis points) } \\
\hline Canada & 9 & -0.8 & & 16 \\
\hline France & 25 & 1.3 & & -5 \\
\hline Germany & 12 & -1.2 & & 22 \\
\hline Italy & 12 & -0.6 & & 12 \\
\hline Japan & 72 & -4.8 & & 90 \\
\hline UK & 38 & 1.4 & & 2 \\
\hline US & 42 & -3.4 & & 62 \\
\hline
\end{tabular}

*Source: October 2010 World Economic Outlook 